\title{
Nas asas da Varig e da Panair: o Conjunto Farroupilha e o espalhamento da música popular brasileira e gaúcha nos anos 50 e 60 do século $X X^{1}$
}

\begin{abstract}
Resumo
Este artigo traz dados do intenso processo de circulação do Conjunto Farroupilha (1948-1993), surgido a partir de uma ideia da soprano Inah Vital (Porto Alegre, RS, 1933-1990), solista da orquestra da Rádio Farroupilha, de Porto Alegre, que reuniu em torno de si, Tasso José Bangel (Taquara, RS, 1931-), Danilo Vidal de Castro (Porto Alegre, RS, 1927-), Estrela d'Alva Lopes de Castro (Livramento, RS, 1934-2015) e Alfeu de Azevedo - depois substituído por Sidney Morais (Sidney do Espírito Santo, Sorocaba, SP, 1925-) -, formando aquele que seria o primeiro conjunto vocal brasileiro a misturar vozes masculinas e femininas. Através de análise etnomusicológica, articulada com aspectos de historicidade e memória acessados a partir da etnografia desenvolvida junto ao Maestro Tasso Bangel, arranjador e líder do grupo, tratamos nessa escrita, especialmente, da primeira fase do Conjunto Farroupilha: de sua constituição, em 1948, em Porto Alegre, como cast da Rádio Farroupilha, até 1960, quando já viviam em São Paulo, tinham gravado seis LPs, conduziam um programa de TV e haviam percorrido o mundo nas asas da Varig e da Panair. Na reconstituição da memória de Tasso Bangel sobre a ampla circulação nacional e internacional do Conjunto Farroupilha, pela via da música, desvela-se a perspectiva de um grupo regional, "gaúcho", sobre o período áureo do "nascimento" e da consolidação da Bossa Nova, quando a música brasileira atingiu um novo patamar de reconhecimento dentro e fora do país.
\end{abstract}

Palavras-chave: Conjunto Farroupilha. Bangel, Tasso. Música Popular - Rio Grande do Sul. Música Popular - Brasil. Bossa Nova.

\author{
Luciana Prass \\ Doutora em Música pela Universidade Federal \\ do Rio Grande do Sul (UFRGS) e professora \\ na mesma universidade. Desde 1993 integra o \\ Grupos de Estudos Musicais - GEM/UFRGS, \\ coletivo interdisciplinar de formação \\ acadêmica e atuação profissional na área de \\ Etnomusicologia / Antropologia da Música. \\ Porto Alegre, Rio Grande do Sul - Brasil \\ luciana.prass@gmail.com
}

\section{Para citar este artigo:}

PRASS, Luciana. Nas asas da Varig e da Panair: o Conjunto Farroupilha e o espalhamento da música popular brasileira e gaúcha nos anos 50 e 60 do século XX. Tempo e Argumento, Florianópolis, v. 9, n. 22, p. 93 -129, set./dez. 2017.

\section{DOI: $10.5965 / 2175180309222017093$}

http://dx.doi.org/10.5965/2175180309222017093

\footnotetext{
1 Colaboraram com esse artigo e integram o projeto de pesquisa, os bolsistas de Iniciação Científica: Gabriela Lery Borges (2014/2-2015/1; 2016/2), Bruno Muck (2016/2-), Kelvin Venturin (2017/1-2017/2), Felipe Barreto Costa (2016/2-) e Aretha Lima (2016/2-2017/1).
} 


\title{
Flying on the wings of Varig and Panair: the Conjunto Farroupilha and the spreading of Brazilian and Gaucho popular music during the $50 \mathrm{~s}$ and $60 \mathrm{~s}$
}

\begin{abstract}
This article presents data from the intense process of circulation of the Conjunto Farroupilha (1948-1993) in Brazil and abroad. A group borned from an idea by the soprano Inah Vital (Porto Alegre, RS, 1933-1990), soloist of the Farroupilha Radio Orchestra, at the city of Porto Alegre, Brazil, who gathered with her, Tasso José Bangel (Taquara, RS, 1931-), Danilo Vidal de Castro (Porto Alegre, RS, 1927-), Estrela d'Alva Lopes de Castro (Livramento, RS, 1934-2015) and Alfeu de Azevedo - later replaced by Sidney Morais (Sidney do Espírito Santo, Sorocaba, SP, 1925-) -, was the first Brazilian vocal ensemble to mix masculine and feminine voices. Through ethnomusicological analysis, articulated with aspects of historicity and memory accessed from the ethnography developed with Tasso Bangel, the group's arranger and leader, this paper is focused, especially, on the first phase of the Conjunto Farroupilha: since its constitution, in 1948, in Porto Alegre, as cast of Radio Farroupilha, until 1960, when they lived in São Paulo, have recorded six LPs, conducted a TV show and have traveled the world on the wings of Varig and Panair. In the reconstruction of Tasso Bangel's memories about the circulation of the Conjunto Farroupilha, through music, emerges the perspective of a regional group, "gaucho", on the golden age of the "birth" and consolidation of Bossa Nova, when Brazilian music reached a new level of recognition within the country and abroad.
\end{abstract}

Keywords: Conjunto Farroupilha. Bangel, Tasso. Brazilian Popular Music. Gaucho Music. Bossa Nova. 


\section{Introdução}

Como imaginar que em meados do século XX um conjunto musical, com características regionais, partindo do sul do Brasil, pilchado², alcançaria longínquos rincões do mundo como a Rússia e a China?

Pois esse artigo pretende trazer dados do intenso processo de circulação do Conjunto Farroupilha (1948-1993), surgido a partir de uma ideia da soprano Inah Vital3 (Porto Alegre, RS, 1933-1990), solista da orquestra da Rádio Farroupilha, de Porto Alegre, que reuniu em torno de si, Tasso José Bangel (Taquara, RS, 1931-), Danilo Vidal de Castro (Porto Alegre, RS, 1927-), Estrela d'Alva Lopes de Castro (Livramento, RS, 1934-2015) e Alfeu de Azevedo - depois substituído por Sidney Morais (Sidney do Espírito Santo, Sorocaba, SP, 1925-) -, formando aquele que seria o primeiro conjunto vocal brasileiro a misturar vozes masculinas e femininas ${ }^{4}$.

Trataremos nessa escrita, especialmente da primeira fase do Conjunto Farroupilha, de sua constituição, em 1948, em Porto Alegre, como cast da Rádio Farroupilha, até 1960, quando já viviam em São Paulo, tinham gravado seis LPs, conduziam um programa de TV e haviam percorrido o mundo nas asas da Varig e da Panair. Como disse o Maestro Tasso Bangel, líder do grupo, "nós promovíamos os eventos da Varig, vendendo o Brasil fora do Brasil, no mundo, aonde a Varig pousava no mundo" (Tasso Bangel, entrevista ao programa Teledomingo ${ }^{5}$ exibido em $1^{\circ} / 06 / 2014$ ).

\footnotetext{
${ }^{2}$ A pilcha é a indumentária de uso no Rio Grande do Sul instituída a partir do Movimento Tradicionalista Gaúcho ainda no final dos anos 40 do século XX, baseada nos trajes usados pelos estancieiros do século XVIII. "E como é que é o vestido das moças: como modelo, aproximado, só havia os vestidos caipiras, das festas juninas de São Paulo, ou as "folhinhas" anuais distribuídas pela Cia. Alpargatas na Argentina. Paixão [Côrtes] encasquetou que deviam ser vestidos compridos até os tornozelos; eu argumentei que se nós, rapazes, estávamos trajando nossas costumeiras bombachas, não carecia que as moças se voltassem para tão longe nos antigamentes; isto não chegou a ser posto em votação, mas o bigodudo Paixão nos venceu pelo cansaço (LESSA, 1985)". A pilcha foi considerada traje de honra e de uso preferencial no Rio Grande do Sul a partir da lei estadual $n^{\circ} 8.813$ de 10 de janeiro de 1989. Em vários festivais de música do estado, até hoje, a pilcha é traje exigido para as apresentações. Para maiores informações e reflexões críticas sobre o gauchismo ver Ferreira, 2014a e 2014b.

3 Em 1951, Inah casaria com Tasso Bangel, adotando o nome Inah Bangel.

${ }^{4}$ Havia outros conjuntos vocais no Brasil à época, entretanto, eram formados apenas por vozes masculinas. Dentre eles, Os Cariocas, uma das grandes referências do Farroupilha.

5 Programa semanal da RBS TV, emissora afiliada da Rede Globo de Televisão. Disponível em <http://g1.globo.com/rs/rio-grande-do-sul/noticia/2014/06/beatles-pararam-para-ver-grupo-do-rs-emlondres-nos-anos-60-diz-musico.html $\geq$. Acesso em 05/08/2017.
} 
A trajetória do Farroupilha é mais um caso que corrobora a constatação do etnomusicólogo Rafael José de Menezes Bastos (2013, p. 9) de que

as músicas populares dos Estados-nação modernos não são, como amiúde se pensa, fenômenos restritos aos respectivos espaços nacionais, fenômenos em relação aos quais o sistema internacional, formado pelos referidos Estados-nação, tivesse importância apenas superveniente.

De fato, é no encontro com o Outro, nessas idas e vindas transnacionais, seja através de deslocamentos físicos, ou a partir das viagens que a escuta per se proporciona - de rádios internacionais, de discos, de shows de grupos internacionais em circulação no Brasil $^{6}$-, que as identidades sonoras, por oposição ou por afinidade, vão se constituindo. Continuando com Bastos,

isso significa dizer que a música popular brasileira não se constituiu (e continua a se constituir) somente no Brasil [...]. [...] A música popular brasileira - vale generalizar esta reflexão para as músicas populares nacionais com um todo - é um universo sociocultural, ele mesmo em trânsito, os modelos que o procuram congelar devendo ser superados a favor de outros que o desenham em movimento [...] (BASTOS, 2013, p. 9 e 11)

Nessa perspectiva e através da análise etnomusicológica, articulada com aspectos de historicidade e memória acessados a partir da etnografia desenvolvida junto ao Maestro Tasso Bangel, arranjador e líder do grupo, é que compartilhamos, nesse artigo, um pouco da trajetória do Conjunto Farroupilha.

\section{De um encontro musical a um projeto de pesquisa}

Foi no ano de 2011 que o Maestro Tasso Bangel (Taquara, RS, 1931) procurou o Instituto de Artes da UFRGS com a ideia de ofertar um curso de extensão na área de composição e arranjos. Estávamos às voltas com a criação de uma graduação em Música

\footnotetext{
${ }^{6}$ Conforme Scarabelot (2004, p. 2), "para termos uma outra perspectiva do movimento jazzista no Brasil dos anos 50 e início dos 60, basta citar alguns dos muitos shows internacionais aqui realizados: Tommy Dorsey (51), Dizzy Gillespie (56), Louis Armstrong (57), Woody Herman (58), Nat King Cole (59), Cab Calloway (59), Sarah Vaughan (59), Ella Fitzgerald (60), Benny Goodman (61). Alguns daqueles shows eram financiados pelo departamento de estado norteamericano".
} 
Popular e por essa razão, o ambiente acadêmico na UFRGS estava se abrindo para experiências como essa, voltadas a práticas de música popular, que se diferenciavam do que vinha ocorrendo até então.

A empatia com o Maestro Tasso foi imediata. Sobretudo, começamos a escutá-lo contar, a cada encontro, um pouco da sua trajetória de músico, nos surpreendendo cada vez mais com sua história, tão ligada à narrativa sobre a música popular do país, mas que, entretanto, não conhecíamos, pois ainda não estava registrada. Nesses encontros, fomos amplificando o desejo e a certeza da necessidade de que sua trajetória fosse reconstituída a partir de um projeto de pesquisa, pois trata-se de uma perspectiva local de um "gaúcho" - sobre o período áureo do "nascimento" e da consolidação da Bossa Nova, os anos 50 aos 70 do século XX, quando a música brasileira atingiu um novo patamar de reconhecimento dentro e fora do país?

Em 2013, quando o Maestro Tasso já nos oferecia cursos de extensão há vários semestres e participava de uma espécie de residência-artística no Departamento de Música, colaborando nas aulas de uma das turmas do recém-criado Bacharelado em Música Popular da UFRGS (2012), ele levou ao Instituto de Artes uma mala de partituras contendo arranjos para variadas formações e criados em distintos períodos de sua vida. Foi nesse momento que resolvemos iniciar um projeto de pesquisa sobre a sua trajetória, baseado na concepção da etnomusicologia entendida enquanto o "estudo das pessoas fazendo música" (TITON, 1997, p. 91), deslocando o foco do estudo da música em si, para o das relações sociais articuladas e potencializadas a partir das práticas musicais.

Graças ao acesso a essas relíquias de sua vida musical, emblemáticas de um tipo de pensamento musical conectado à estética da Bossa Nova, mas voltado também a repertórios de música regional sulriograndense, que iniciamos o projeto que tem buscado traçar a trajetória do Maestro Tasso Bangel a partir das memórias suscitadas em entrevistas, regadas à escuta compartilhada de seus discos e ao encontro com materiais de seu acervo pessoal a nós disponibilizados como fotografias, recortes de jornais,

\footnotetext{
7 Lembrando, claro, dos movimentos de internacionalização já ocorridos intensamente em períodos anteriores, nos anos 20, com Pixinguinha e os Oito Batutas, indo à França e à Argentina (COELHO, 2013) e no final dos anos 30 com Carmen Miranda, o Bando da Lua, Garoto e Ary Barroso invadindo a cena norteamericana (CASTRO, 2005).
} 
artigos de revistas, capas de discos, bilhetes e partituras. Lembrar através da música (ALBERNAZ, 2013), especialmente do seu período como integrante e arranjador do Conjunto Farroupilha, tem nos permitido desvelar informações importantes sobre a música e o cenário musical do Rio Grande do Sul e do Brasil no século XX8 .

\section{Taquara e Porto Alegre: a paisagem sonora dos primeiros anos de Tasso Bangel}

Foi em Taquara, interior do Rio Grande do Sul, que Tasso Bangel iniciou na música. Acompanhando a mãe que cantava no coro da igreja católica da cidade, abriu seus ouvidos à música a partir de arranjos vocais. Disso surgiu o desejo de estudar piano que, em seguida, ainda menor de idade, aos 12 anos, o levou ao acordeom e com ele, às primeiras experiências profissionais em uma jazz band ${ }^{9}$ em sua terra natal:

[...] O acordeom já tinha chegado na minha vida porque com 12 anos [1945] eu comecei a tocar numa orquestra que tinha o nome de Jazz Brasil, na minha cidade, Taquara. E nessa época, por causa da influência nossa, também da rádio que vinha da Rádio El Mundo, da [Rádio] Belgrano, de Buenos Aires, e de Montevideo, das rádios que vinham pelo pampa. [...] Eu tinha que pegar o acordeom com essa banda, com essa orquestra que eu tocava, porque se não tocasse tango... tinha que ter! Quer dizer, [nos shows] a música brasileira e a música instrumental se tocava o quê? Meia-hora, quarenta e cinco minutos? Mas os outros quinze minutos, meia-hora, tinham que ser de tango, por causa da influência que nós tínhamos aqui do campo que vinha da Argentina e do Uruguai, fortemente. (Tasso Bangel, depoimento em aula ${ }^{10}$ em 20/10/2013)

\footnotetext{
${ }^{8}$ Prass, Luciana. “Tasso Bangel e o 'eterno aprender': a trajetória do maestro/arranjador/compositor/cantor/instrumentista, do Conjunto Farroupilha (1948-1990) à Camerata Pampeana (2010)". Projeto de Pesquisa. Departamento de Música, Instituto de Artes, UFRGS. 2013. $<$ https://www.ufrgs.br/tassobangel/2.

9 Faria (2001, p. 86), explica a explosão de jazz bands no RS, a partir dos anos 20: "A década de 10 viu aparecer no Brasil os primeiros ritmos americanos a se espalharem pelo mundo: o charleston, o ragtime, 0 fox-trot e os hoje praticamente desconhecidos shimmy, cake-walk, on-step e black-bottom. A primeira grande mudança resultante disso foi na formação musical dos grupos de música popular. 'Jazz' tornou-se, antes do que um gênero, um nome para designar determinado tipo de conjunto de instrumentistas: alguns sopros e uma cozinha rítmica formada por banjo e/ou piano, contrabaixo (ou tuba) e bateria. Aqui no sul, foram uma febre avassaladora. E tocavam de tudo: maxixes, polcas, shottisches, habanera e até, ora vejam só... jazz". Além desses gêneros musicais, como o depoimento do Maestro Tasso Bangel citado acima explicita, também tocavam tango.

${ }^{10}$ Participação do Maestro Tasso Bangel em aula de Música Popular do Brasil II, no segundo semestre de 2013, na UFRGS, ministrada por Luciana Prass.
} 
É desses primeiros tempos também algumas das marcas sonoras transnacionais que viriam influenciar definitivamente sua trajetória musical: o tango, através das já citadas rádios argentinas e uruguaias e a música norte-americana, que invadia o Brasil no pós-Segunda Guerra mundial: “[...] na época da guerra também, o que eu ouvia, que não era cultura jazzística, ou seja, norte-americana, [...] era tango" (Tasso Bangel, depoimento em aula 20/10/2013). E continua: "durante a Guerra os norte-americanos nos enchiam de sua música. Glenn Miller, Tommy Dorsey, Gerswin, eu tocava feito louco!" (Tasso Bangel, comunicação pessoal em 16/03/2011).

Falando da época em que, aos 16 anos, transferiu-se de Taquara, no interior, para a capital, Porto Alegre, para ingressar no Colégio Julio de Castilhos e para estudar música no Instituto de Bellas Artes - hoje Instituto de Artes da UFRGS -, Tasso citou ainda as gravadoras estrangeiras que editavam discos no Brasil.

Então essa época eu tinha 16 anos e tinha ouvido muito, muito, música norte-americana, de gravações, de cantores, de tudo o mais. Durante a guerra toda eu ouvi. Quando terminou a guerra começou uma influência muito forte de música norte-americana ainda, dentro do Brasil. Mas daí [...] já tinha gravações formidáveis vindas de outras nações para prensar no Brasil e a RCA Victor, a Columbia, a Odeon, que são gravadoras americanas e inglesas, e francesas algumas também, que já editavam discos no Brasil, e esses discos eram tocados nas rádios. (Tasso Bangel, depoimento em aula em 20/10/2013)

O músico e jornalista Arthur de Faria, em “Um século de música”, afirma que além das músicas estrangeiras que povoavam o imaginário sonoro do país, com a Revolução de 30 e a ascensão de Getúlio Vargas ao poder, o samba foi adotado como música nacional, “simplesmente porque o samba era a música nacional daquele país sediado no Rio de Janeiro, a Cidade Maravilhosa, a Capital da República. E onde estavam, é bom frisar, as principais gravadoras e rádios, distribuindo suas ondas e seus produtos para todo o Brasil" (FARIA, 2001, p. 105).

Como consequência e reflexo disso - da instituição de uma música nacional, no caso, o samba -, o antropólogo Hermano Vianna (1995, p. 70) defende que "o samba vira símbolo nacional, ao passo que as canções 'caipiras' paulistas e os ritmos nordestinos 
começam a ser vistos como fenômenos regionais". Isso também acabou ocorrendo com a música produzida no Rio Grande do Sul.

Sendo assim, para Faria, a produção de música no estado - porque "fenômeno regional" - não conseguia se desenvolver. Para o autor,

o curioso é que por 'música brasileira' entendia-se aquela noventa por cento feita no Rio de Janeiro, por cariocas, baianos, mineiros e um que outro paulista ou pernambucano. Com todas as rádios e orquestras daqui [do RS], à época [final dos anos 1940], a situação era basicamente a mesma. [...] Entre os anos 30 e 50, um ET que baixasse por aqui concluiria que os gaúchos tinham uma curiosa espécie de bloqueio, que os impedia de compor música que tocasse no rádio ou virasse disco"11. (FARIA, 2001, p. 103)

Nesse caso, a musicalidade sulriograndense, sua herança vinda do interior do Rio Grande do Sul, mas também aquela de personalidades importantes à cena popular da capital, Porto Alegre, do início do século XX - dentre elas, Octávio Dutra ${ }^{12}$, por exemplo -, entraram em um total obscurecimento frente ao que era divulgado neste período, na chamada "Era do Rádio": especialmente a música do centro do país e, ainda, a música norte-americana.

\section{Carteira assinada na Rádio Farroupilha}

É nesse cenário que Tasso Bangel, então com 17 anos, se aproxima da Rádio Farroupilha $^{13}$, a poderosa rádio inaugurada em 1945, ano do centenário da Revolução Farroupilha, que possuía uma jazz sinfônica para apresentações musicais ao vivo ${ }^{14}$.

\footnotetext{
${ }^{11}$ Faria refere-se a Lupicínio Rodrigues, como um dos poucos músicos do sul que gravou no período, justamente porque fazia samba, "[...] ignorando totalmente o convívio que teve com os mesmos músicos que, nas décadas de 10 e 20, misturavam schottisches, polkas, valsas, mazurkas, habaneras, batucadas de negros, tarantelas italianas, fandangos ibéricos e algumas quase extintas raízes açorianas naquele melting pot porto-alegrense" (FARIA, 2001, p. 107).

${ }^{12}$ Para mais informações sobre Octávio Dutra, "O terror dos facões", ver Souza (2016).

13 "De propriedade de fortes aliados do Governo Vargas, a nova emissora [Rádio Farroupilha] entra em cena já como a mais potente do Brasil. São 25kW, que só seriam superados pelos $26 \mathrm{~kW}$ da Tupi de São Paulo de Assis Chateaubriand - dois anos depois" (FARIA, 2001, p. 101).

${ }^{14}$ Ver também Schmitt (2008).
} 
[...] A Farroupilha tinha naquele tempo o que é hoje a jazz sinfônica: ou seja, eram seis primeiros violinos, seis segundos, três ou quatro violas, dois ou três cellos, baixos, [...] trio de trompetes, três trombones, quarteto de sax, porque não tinha barítono, sax barítono. Mas era uma jazz sinfônica, naquele tempo, as orquestras [...]. (Tasso Bangel, comunicação pessoal em 10/04/2017)

Faria corrobora essa informação e acrescenta que

desde a década de 1940, e indo até o início dos anos 60, havia uma grande rivalidade entre quem cantava, tocava ou integrava as orquestras da Gaúcha e da Farroupilha. A Grande Orquestra Farroupilha era inequivocamente a mais completa: big-band com todos os naipes fechados no padrão Glenn Miller, o grande referencial da época: cinco saxes, quatro trompetes, quatro trombones, guitarra, piano, contrabaixo e bateria, mais ritmistas e muitos cantores. A isso somava-se também uma orquestra de câmara também completa: primeiros violinos, segundo violinos, violas, cellos, contrabaixos, oboé, clarinetes, fagote, trompa, etc. Coisa de mais de 60 músicos, regidos pelo italiano Salvador Campanella, assessorado pelos maestros Roberto Eggers [...] e Alfred Hulsberg [...] (FARIA, 2001, p. 121 -122)

Foi nesse contexto, de grandes orquestras ligadas às emissoras de rádio influenciadas pela explosão das sonoridades das jazz bands norte-americanas, que Tasso Bangel recebeu o convite para ser o arranjador do Conjunto Farroupilha, grupo vocal que viria a se formar na rádio homônima, na esteira desse grande movimento musical.

A sugestão para que existisse esse conjunto começou com a minha esposa, a Inah, solista, seria a minha futura esposa. Isso em 48. Ela era a primeira cantora daqui, sempre foi a primeira cantora do Rio Grande do Sul. [...] Então, ela não gostava de cantar... e sozinha, ainda, muito menos. [...] Num momento ela disse "Quero fazer um grupo vocal" junto com o irmão dela, que acompanhava ela sempre na noite, pra sair, essas coisas. E chegou aos ouvidos de Salvador Campanella, que era dirigente da Rádio Farroupilha de Porto Alegre. [...] E o Campanella disse "Por que vocês não fazem com aquele guri que tá tocando acordeon ali, que tá estudando lá no Belas Artes? Ele pode fazer tudo pra vocês, escrever as coisas." E o irmão da Inah, Danilo, seria outro integrante do Farroupilha. Inah, Danilo, o irmão, a esposa dele, Estrela Dalva. [...] Então daí foi que começou o Conjunto. [...] Foi num dia 20 de setembro de 1948, na data Farroupilha, que nós fizemos nosso primeiro ensaio do Conjunto Farroupilha. (Tasso Bangel, comunicação pessoal em 10/04/2017) 
Vale dizer que a existência de orquestras nos moldes das norte-americanas impulsionou um grande desenvolvimento de arranjadores no país, dentre os quais, Pixinguinha (1897-1973) e, posteriormente Radamés Gnattali (1906-1988), entre outros, na Rádio Nacional, bem como, os citados Salvador Campanella (1907-1985) e Roberto Eggers (1899-1984) ${ }^{15}$, na Rádio Farroupilha, e Karl Faust (s/d), na Rádio Gaúcha - que foram transformando seus arranjos, incorporando modos de orquestração das jazz bands, especialmente as propostas nos naipes de metais (trompetes, trombones) e madeiras (saxofones, flautas, clarinetes) (BARBOSA; DEVOS, 1985; JOBIM, 1996; FARIA, 2001). No caso do Maestro Tasso Bangel, essas sonoridades jazzísticas foram incorporadas nos seus arranjos vocais criados para o Conjunto Farroupilha.

E eu fui pra Radio Farroupilha e foi proposto que eu fosse o arranjador de um grupo que nascia naquele ano, 1948. Eu tinha 16 anos. 17 anos. Eu sou de 31 então em 49 eu tinha 17 anos. Mas aos 16 eu tava na Farroupilha já... com carteira assinada! Muito cedo eu me aposentei, pude me aposentar, como músico e tudo o mais, porque, bah, com 16 anos eu já tinha carteira assinada! (Tasso Bangel, depoimento em aula em 20/10/2013)

A influência da música norte-americana era tanta que o primeiro arranjo executado pelo Conjunto Farroupilha, ao contrário do que se poderia imaginar conhecendo a carreira do grupo a partir de seus primeiros discos, foi de “Please, don't say no, say maybe", de Sammy Fain e Arthur Freed, sucesso em $1945^{16}$.

Daí a curiosidade: "a primeira música que vocês cantaram era gaúcha?" Não! [risos] "Mas então qual foi a música que vocês cantaram?" Tenho certeza que aqui ninguém conhece, não lembra da música, mas foi uma música de grande sucesso no Brasil que dizia "Please don't say no, say maybe" [cantando]. (Tasso Bangel, depoimento em aula em 20/10/2013)

\footnotetext{
${ }^{15}$ Roberto Eggers viria a ser professor de Bangel. "Estudei, comecei a estudar harmonia pra valer com o maestro Roberto Eggers, maestro lá da Rádio Farroupilha [...]. Então, com o Eggers que eu mergulhei mesmo na harmonia e na orquestração. [...] Compositor, orquestrador, arranjador da Rádio Farroupilha, que eu vim conhecendo mesmo (Tasso Bangel, comunicação pessoal em 24/09/2013).

${ }^{16}$ A primeira orquestração de Tasso Bangel foi também de um sucesso norte-americano, composição de Sidney Lippman e Sylvia Dee, de 1951, gravada no mesmo ano por Nat King Cole: "Meu primeiro arranjo pra orquestra foi Nat King Cole [cantarola melodia]. Como era mesmo a melodia? A melodia que o Nat King Cole... Too Young, era fantástica, sucesso dele" (Tasso Bangel, comunicação pessoal em 16/3/2011).
} 
Mas foi na sequência da estreia do Conjunto Farroupilha que os então jovens folcloristas, Barbosa Lessa e Paixão Cortes, foram procurar Tasso Bangel na Rádio Farroupilha, para mostrar as músicas "gaúchas"17" que vinham compondo a partir de suas pesquisas no interior do estado (CÔRTES; LESSA, 1987), com o intuito de que o Farroupilha passasse a executá-las e a difundi-las. Mas como demonstra o depoimento do Maestro Tasso, essa não era a cultura musical a que eles estavam acostumados.

O meu mundo era um mundo um pouquinho diferente do que estavam querendo o Paixão e o Lessa ao mesmo tempo. Então nessa época, gente, essas bandinhas que eu ouvia na colônia [em Taquara, RS], não tocavam música do RS, a não ser xote, que é de origem schottische [...]. Então as bandinhas tocavam xotes, tocavam rancheiras que é de origem da mazurca, as valsas e coisinhas assim. Samba era muito pouco! E era difícil! Quando tocava [samba] era de uma forma... na minha memória, era uma coisa horrorosa. Uma coisa que não era bom, [que não era] gostoso de ouvir. (Tasso Bangel, depoimento em aula em 20/10/2013)

Perguntado sobre qual era a música gaúcha que era veiculada nesse período anterior ao início do Conjunto Farroupilha, o Maestro explicou

Os Irmãos Bertussi ${ }^{18}$ ainda não. Os Bertussi depois. Tinha o Pedro Raymundo: "Nasci lá na cidade me casei na serra..." [cantando trecho de "Adeus, Mariana"]. Era isso, quer dizer, de cantores muito pouca coisa. Eram os trovadores, a trova que sempre foi o forte do Rio Grande, né? Interiorana, mas a canção gaúcha do interior não era praticada porque não tinha quem comprasse, essa é a verdade. Não tinha mercado ainda. Então não surgia compositores porque não tinha mercado! O mercado é que faz tudo. É isso aí. Então, pouca coisa. (Tasso Bangel, comunicação pessoal em 10/04/2017)

\footnotetext{
17 A expressão "música gaúcha" muitas vezes é utilizada como sinônimo de música sulriograndense, entretanto, denotando, na maioria das vezes, um tipo de música que enfoca o tema poético musical agropastoril, afinada às proposições do Movimento Tradicionalista Gaúcho, tal como pensado por Barbosa Lessa e Paixão Cortes (1987 [1955]). Todavia, tal expressão, especialmente dos anos 80 do século XX em diante, é tema de disputas sobre "autenticidade" versus diversidade musical nas expressões musicais do Rio Grande do Sul. Para aprofundar essa reflexão, ver Ferreira (2014a) e Lucas (1990, 1994).

18 “Em 1954, aproximadamente na mesma época em que o Conjunto Farroupilha despontava com suas gravações de temas folclóricos do sul do país, os Irmãos Bertussi (Adelar [1933-] e Honeyde [1923-1996] seguiam para o Rio de Janeiro buscando um espaço no cenário musical do centro do país. Em dezembro de 1955, a dupla Irmãos Bertussi lançou seu primeiro disco, Coração Gaúcho [...]. Utilizando dois acordeons, cantando, na maioria das vezes, em dueto de vozes e vestindo bota, lenço, chapéu, bombacha e tirador, eles fizeram sucesso no país gravando composições próprias, baseadas em temáticas rurais e festivas assim como alguns temas folclóricos [...]” (ÁVILA, 2015, p. 10-11).
} 
Entretanto, o encontro com Lessa e Cortes, em 1948, marcou indelevelmente a trajetória do Farroupilha que passou a executar músicas gaúchas em seu repertório - em sua grande maioria, compostas por eles - e a usar pilcha em suas performances ${ }^{19}$. Mas toda a bagagem musical anterior dos integrantes do grupo vinha expressa nos arranjos e nas orquestrações do Farroupilha que carregavam a marca das harmonias jazzísticas e dialogavam com outros grupos vocais tanto brasileiros, "Os Cariocas", quanto norteamericanos, como os conjuntos de Glenn Muller, Artie Shaw e "The Pied Pipers", de Tommy Dorsey.

Grupos grandes, vocais. Bom, Estados Unidos eu gostava de todos eles, né? [...] Eu gostava demais dessa época da música norte-americana. De Glenn Miller, Tommy Dorsey, Artie Shaw. Tudo, grandes músicos, grandes artistas do tempo da música norte-americana, né? Tinha o conjunto que era do Glenn Miller ou do Tommy Dorsey, não sei bem, tinha nome de The Pied Pipers. The Pied Pipers eram duas mulheres cantando e três homens cantando. Gostava, eu adorava esse grupo vocal porque os americanos... [...] também cantavam com voz aguda como os Cariocas, mas sempre, todos os grupos americanos com voz feminina ponteando sempre, né? Daí um estilo meu para o Farroupilha. (Tasso Bangel, comunicação pessoal em 10/04/2017)

O sucesso do Farroupilha foi tanto que, já em 1950, apenas dois anos depois de sua estreia, na Rádio Farroupilha, o Conjunto foi convidado para participar da primeira transmissão de TV do país, na Tupi, de São Paulo, e dali partiu o convite para gravar o primeiro disco, “Gaúcho"20, em 1952, ainda em 78 rotações, pela Copacabana.

[...] Foi o primeiro disco que nós gravamos. Era um dez polegadas, não tinha o doze [polegadas] ainda. Não era ainda o doze polegadas, que é o Long Play. [...] Long play era geralmente doze faixas, né? E o 78

\footnotetext{
${ }^{19}$ Antes do Farroupilha, Pedro Raymundo já levara a pilcha para os palcos do país. "Na década de 1940, rumava para o centro do país o gaiteiro Pedro Raymundo (1906-1973), natural de lamruí/Santa Catarina, já com uma carreira estruturada no RS ao lado do grupo Quarteto dos Tauras (Lopes; Minas, 1986). No Rio de Janeiro lançou seu primeiro disco e fez sucesso nacional com a música Adeus Mariana, apresentando-se nos programas de auditório trajado com bombacha, bota, guaiaca e lenço. Ganhou o apelido de 'Gaúcho Alegre do Rádio' e se tornou o primeiro artista da música regional do RS a ter projeção nacional, sendo em 1950, capa da Revista do Rádio" (ÁVILA, 2015, p. 10).

${ }^{20}$ Faixas do disco "Gaúcho" (1952): 01 - Balaio (Barbosa Lessa / Paixão Cortes); 02 - Tatú (Barbosa Lessa / Paixão Cortes); 03 - Negrinho do Pastoreio (Barbosa Lessa); 04 - Me Dá Um Mate (Barbosa Lessa); 05 Chirimindé (Barbosa Lessa / Paixão Cortes); 06 - Amargo (A. Amábile / Lupicínio Rodrigues); 07 Carreteiro (Barbosa Lessa); 08 - Rancheira da Carreirinha (Barbosa Lessa). Áudios disponíveis em $<$ https://www.ufrgs.br/tassobangel/>.
} 
[polegadas], esse primeiro disco foi em 78 rotações, [...] eram oito músicas, quatro de cada lado. E os Long Plays, seis de cada lado. (Tasso Bangel, comunicação pessoal em 10/04/2017)

Nesse primeiro disco, duas coisas precisam ser ressaltadas: todas as faixas continham música do Rio Grande do Sul - todas de autoria de Barbosa Lessa ou em parceria dele com Paixão Cortes, à exceção de "Amargo", de A. Amábile e Lupicínio Rodrigues - e, uma questão que se tornará uma das marcas registradas do Conjunto Farroupilha, metade do disco foi gravada com orquestra, nessa ocasião com arranjos de Aldo Taranto ${ }^{21}$. A junção do Conjunto com acompanhamento de orquestra foi, segundo Tasso Bangel, uma definição que partiu de Inah, a principal cantora do grupo.

Ela [Inah] sempre gostou de orquestra. [...] Então, desde essa primeira gravação, nós fizemos um acerto, entre ela e eu: Olha, tudo que surgir na nossa vida... lógico, nós vamos tocar o som do Rio Grande do Sul, com acordeom, violão. Foi assim que nós chegamos... São Paulo, Rio! E estando no Rio, eles nos ouviram e disseram "Vamos gravar, vocês vão pro estúdio". "Não, não, não, não! Não é assim: vamos pro estúdio!” "Mas por que não?" "Se não tiver orquestra, nós não gravamos!" "Como, orquestra? Orquestra custa caro!" "Não é problema meu. Se não tiver, nós não gravamos!" “Então como é que vai ser?" Entreguei a partitura com a cifra pro Aldo [Taranto]. "Então quem vai orquestrar é o Aldo Taranto." Então, sempre foi assim, se não tivesse orquestra... Nós sempre gravamos fifty-fifty [... ] (Tasso Bangel, comunicação pessoal em 10/04/2017)

Foi assim, firmando posição, que o Conjunto Farroupilha tocou e gravou sempre com orquestras os acompanhando, vindo a trabalhar com "ases da música brasileira", nas palavras do Maestro Tasso.

Então eu dava partituras de seis [músicas] que seriam orquestradas e quando eu não orquestrava dava [para outros]. [...] Quem orquestrou pra nós? Ases da música brasileira! Olha, um disco nosso foi orquestrado pelo Lyrio Panicali. Lyrio Panicali, bah... Rádio Nacional do Rio de Janeiro. Era ele e o Radamés Gnattali, só homens conversados! São fantásticos! O Lyrio era linda, linda criatura. Outro que nós insistimos em gravar foi o

\footnotetext{
${ }^{21} \mathrm{~A}$ informação fornecida pelo Maestro Tasso de que este primeiro disco foi entregue ao Presidente Getúlio Vargas dá ideia das redes de relacionamento nas quais o Farroupilha se inseria. Sem dúvida, o fato de ser um grupo gaúcho e ligado, à época, a uma emissora de rádio aliada ao sistema da Rádio Nacional, do grupo Chateaubriand, facilitou esse trânsito.
} 
Simonetti, o Enrico Simonetti ${ }^{22}$, um italiano... maravilhoso, a cultura maravilhosa, linda, entre outros [arranjadores]. Coisas minhas também que orquestraram. Quando ficava apertado, eles faziam dois, três arranjos e eu fazia os outros. (Tasso Bangel, comunicação pessoal em 10/04/2017)

\section{A mudança dos Farroupilhas para São Paulo}

Em 1950, como vimos, os Farroupilhas foram convidados a participar quando da primeira transmissão televisiva no Brasil, na TV Tupi, de São Paulo. Essa experiência suscitou o desejo de retornar ao centro do país. Com o sucesso do primeiro disco, essa possibilidade tornou-se, aos poucos, mais concreta. Mas foi somente em 1956, que o Conjunto decidiu mudar-se definitivamente para São Paulo, a partir de contrato com as TVs Tupi e Record, para um programa semanal chamado Gessy 21 e $30^{23}$ (HERÊNCIO, 2017). E nesse mesmo ano gravaram seu primeiro Long Play (LP), que foi o $4^{\circ} \mathrm{LP}$ gravado no Brasil, o que demonstra a importância e o sucesso do Conjunto Farroupilha nesse momento, no país ${ }^{24}$.

Nesse LP, concretizou-se outro procedimento que viria a ser também marca registrada do grupo: a variedade de repertórios. A partir do primeiro disco, gravado com exclusividade de repertório do Rio Grande do Sul, em "Conjunto Farroupilha - de norte a sul" (1956), a seleção de faixas incluiu músicas e compositores de São Paulo, Alagoas, Bahia, Pernambuco e Pará, além do Rio Grande do Sul, demonstrando a grande versatilidade do Conjunto, ainda em sua faceta "regional", mas agora ampliada para os regionalismos de outras partes do país ${ }^{25}$. Na contracapa do LP se lê:

\footnotetext{
${ }^{22}$ No Brasil, Enrico adotou a grafia Henrique para seu nome.

23 Programa patrocinado pela Cia. Industrial Gessy Lever, uma das dez maiores anunciantes e, portanto, das maiores investidoras em propaganda no país, à época (MUSTAFÁ, 2014).

24 “O $1^{\circ}$ LP gravado no Brasil foi do Radamés [Gnattali]; o $2^{\circ}$, do Silvio Caldas; o $3^{\circ}$ Waldir Calmon e o $4^{\circ} \mathrm{LP}$, de 10 polegadas, foi do [Conjunto] Farroupilha" (Tasso Bangel, comunicação pessoal em 16/03/2011).

${ }^{25}$ Faixas do disco "Conjunto Farroupilha - De Norte a Sul”, de 1956: 01 - Chimarrita (Dilú Mello); 02 - Tristeza do Jeca (Angelino de Oliveira); 03 - Favela (Hekel Tavares / Joracy Camargo); 04 - Festa De Rua (Dorival Caymmi); 05 - É de Tororó (Ariano Suassuna / Ascenso Ferreira / Capiba); 06 - Vento Terra (Gilvan Chaves); 07 - Boi Bumbá (Waldemar Henrique); 08 - Piazito Carreteiro (Luiz Menezes). Áudios disponíveis em <https://www.ufrgs.br/tassobangel/>.
} 
Em pleno sol baiano os gaúchos cantam a "Festa de Rua" que Caymmi fez para mostrar festejos populares de sua terra e em seguida as vozes sobem ao mar morto e chegam em festejos pernambucanos para assistir um maracatu e cantar depois sua dolência na beleza poética que Capiba compoz [sic]: o clássico "É de tororó" [...]. A característica principal do "Conjunto Farroupilha" é o bom gôsto [sic] na escolha de seu repertório e a autenticidade que êle [sic] imprime em cada canção regional. Eles cantarão o "Vento Terra" lá de Alagoas, como o "Boi Bumbá", das festas natalinas do Pará ou Amazonas. Com a beleza da escolha dêsse [sic] punhado de melodias tão nossas, ganhamos percorrer terras as mais variadas, pelo colorido de interpretação que essas vozes emprestam. $(\mathrm{S} / \mathrm{A}, 1956)$

Nesse momento, essa espécie de defesa das músicas regionais, incorporadas à estética do grupo pela via dos arranjos vocais jazzísticos, era o viés que o mercado fonográfico do país percebia como uma potencialidade do grupo. Era também o momento em que o chamado “Movimento Folclórico Brasileiro" (1947 - 1964) vivia seu auge, articulando "o engajamento de um expressivo contingente de intelectuais na valorização da cultura popular, concebida por eles não apenas como um objeto de pesquisa, mas principalmente como o lastro para a definição de nossa identidade nacional” (VILHENA, 1997, p. 21) ${ }^{26}$. Na esteira desse “Movimento”, a indústria fonográfica também elaborava a sua proposta baseada em sua interpretação mercadológica do folclore. E nela, entre outros grupos, estava inserido o Conjunto Farroupilha.

Morando no centro do país e fazendo sucesso no Rádio e na Televisão, nesse mesmo ano, o Conjunto Farroupilha foi escolhido como "o melhor conjunto vocal do ano" de 1956 pela Revista do Rádio. O Jornal A Noite noticiou assim o fato:

Foi uma eleição merecidíssima a qual se verificou pela quase unanimidade dos votantes, ou sejam, 26 sufrágios, num total de 29. 0 Conjunto Farroupilha foi formado em setembro de 1948, atuando na Rádio Farroupilha em Porto Alegre. Só em meados, porém, de 1956, seus componentes resolveram transferir-se para esta capital, assinando contrato com a Rádio e a Televisão Tupi. Seu principal objetivo é difundir o folclore gaúcho, o que não o impede de incluir no seu repertório músicas de todo o Brasil e melodias internacionais [...]. A verdade é que, em menos de seis meses, o Conjunto Farroupilha realizou o milagre de conquistar a Capital Federal, tornando-se uma das maiores atrações de nosso "broadcasting", e na televisão. Os aplausos e elogios são

\footnotetext{
${ }^{26}$ Ver também Prass (2013) sobre o movimento folclórico no Rio Grande do Sul e a realização das primeiras gravações de campo no estado por Luiz Heitor Correa de Azevedo e Ênio de Freitas e Castro.
} 
unânimes a todos os que o têm visto atuar. O Conjunto Farroupilha é alguma coisa de diferente, de original e de moderno [...]. A recente decisão dos críticos especializados não foi mais que uma plena ratificação do que estava no consenso dos ouvintes e televentes [sic] dessa capital [...] (A Noite, 1957)

\section{Farroupilhas em Alta Fidelidade}

Com todo esse reconhecimento alcançado em seu primeiro ano vivendo no centro do país, não é de se surpreender que no ano seguinte, em 1957, o Conjunto Farroupilha seja escolhido como um dos primeiros grupos a gravar um LP com a nova tecnologia de alta fidelidade - Hi-Fi -, recém-chegada ao Brasil. Em “Gaúchos em Hi-Fi”, LP da Columbia, o Farroupilha retoma o foco no repertório de tradição gaúcha, mas agora aproveitando todos os recursos tecnológicos para dar a escutar sua musicalidade regional com arranjos "modernos" assinados por Henrique Simonetti, dentre eles o de "Negrinho do Pastoreio", composição de Barbosa Lessa, que levará o disco a vender a surpreendente marca de 700.000 cópias nesse ano.

Nesse momento, iniciava-se o período de Juscelino Kubitschek (1956-1961) na Presidência da República. Com o lema "50 anos em 5", o conceito de "modernidade" invadia o mundo da cultura no país: iniciava-se a construção de Brasília (inaugurada em 1960), projeto de linhas “econômicas”, “modernas”, de Oscar Niemeyer, assim como novas estradas e parques industriais; o Cinema Novo tinha feito sua estreia em 1955 com “Rio, 40 graus", de Nelson Pereira dos Santos; a poesia concreta avançava com Augusto de Campos, Décio Pignatari, entre outros; na música erudita, movimentos nacionalistas na esteira de Villa-Lobos conviviam com a nascente influência das vanguardas musicais europeias chegadas ao país na bagagem do compositor alemão Hans-Joachim Koellreutter ${ }^{27}$.

É nesse contexto que a Bossa Nova começa a tocar seus primeiros acordes, em sintonia com esse grande movimento modernista que buscava "a concisão, a objetividade e a racionalidade" (NAVES, 2004, p. 18). Para Naves, a gravação de "Chega de Saudade", de Tom Jobim e Vinícius de Moraes, em 1958, por Elizeth Cardoso marca o início da Bossa

\footnotetext{
27 Data de 1946 o “Manifesto Música Viva" que entre outras questões, refutava a "música acadêmica” e defendia a música popular.
} 
Nova, porém, ainda sem romper com o que ela chamou de "estética do excesso" (NAVES, 2004, p. 10). Para a autora, um dos aspectos desse "excesso" eram justamente os grandes e pomposos arranjos instrumentais construídos no período para acompanhar as canções. Além disso,

também fazia parte dessa estética excessiva, a performance dos cantores e a interpretação, em termos tanto vocais quanto instrumentais. Os cantores, principalmente nos anos 40 e 50, obedeciam ao estilo operístico, soltando a voz ao máximo e exibindo-a com floreios os mais variados. Com relação à sua interpretação, era comum o cantor construir uma persona exuberante, recorrendo a trajes reluzentes e a uma postura teatral. (NAVES, 2004, p. 11)

Com arranjos de Tom Jobim, e o nascente violão de João Gilberto - nessa época ainda músico do cast de gravadoras, ainda sem a projeção que viria a ter no futuro próximo -, o disco de Elizeth Cardoso foi um estrondoso sucesso. Mas, para Naves, ainda não era Bossa Nova. Comparando Tom Jobim e João Gilberto, a autora defende que

Tom Jobim, embora versátil enquanto compositor, já aparecia no cenário bossa-novista com uma estética bastante marcada pelo excesso. Se João adotava uma postura mais camerística, Tom se voltava para os recursos sinfônicos. É como se ambos interpretassem o momento histórico em que viviam de maneiras diferentes: João à maneira construtivista que marcava a década, tanto na literatura quanto na arquitetura e nas artes plásticas, e Tom a partir do ponto de vista do modernismo musical, representado, por exemplo, por Villa-Lobos. (NAVES, 2004, p. 18)

Se eram "excessivos", por sempre disporem de arranjos orquestrais e usarem pilchas (isso já em processo de transformação), os Farroupilhas eram também “modernos", por suas performances de harmonias vocais com acordes jazzísticos e de entonação sem vibratos.

\section{"Varig, Varig, Varig"28": Farroupilhas na Argentina e Europa}

Com um repertório que além de músicas gaúchas, incluía agora músicas regionais representativas de várias partes do país, o Conjunto Farroupilha inicia um período de

\footnotetext{
${ }^{28}$ Menção à assinatura rítmico-melódica dos populares jingles da extinta empresa aérea.
} 
muitas viagens internacionais, várias delas fruto de parceria entre o Ministério das Relações Exteriores e a Varig, empresa de transporte aéreo, em franca ascensão à época.

Dentre uma série de viagens que sucederam ao sucesso de "Gaúchos em Hi-Fi", Tasso relatou uma temporada do Conjunto Farroupilha em Buenos Aires, junto ao Moulin Rouge $^{29}$ que, segundo ele, possuía uma orquestra grande regida por Jean D’Arco ${ }^{30}$. Jean D’Arco também era regente de Carlos Machado ${ }^{31}$ com quem o Conjunto Farroupilha já havia trabalhado. Ao lado do Moulin Rouge já não tocavam pilchados.

Houve uma época boa, [...] que nós fomos contratados para trabalhar em Buenos Aires com o Moulin Rouge. Nós fizemos um mês e meio em Buenos Aires com o Moulin Rouge e fizemos Mar del Plata. Depois fomos pra Montevideo, fizemos Montevideo, fizemos [...] Punta del Este. (Tasso Bangel, comunicação pessoal em 10/04/2017)

$\mathrm{Na}$ esteira do sucesso dessa temporada, um importante empresário ligado ao Moulin Rouge levou o grupo para uma série de concertos na Europa.

Depois que nós fizemos aquela temporada com o Moulin Rouge, [...] o mágico que trabalhava com o Moulin Rouge, [ele] era um grande empresário na Europa. Então ele nos levou, nos vendeu para Londres, nos vendeu para Paris, Europa, França. Europa toda, trabalhamos muito lá. E daí então, ficamos conhecidos. (Tasso Bangel, comunicação pessoal em 10/04/2017)

Com as viagens, o Conjunto passou a incorporar também canções internacionais em sua set list.

Quando viajávamos, antes a Varig nos dizia a música do momento naquele país para onde iríamos, e então, preparávamos um repertório com canções que eles já conheciam e faziam sucesso lá, no momento. Aprendíamos, orquestrávamos, ensaiávamos e quando chegávamos lá, nós começávamos cantando o sucesso da terra naquele momento. (Tasso Bangel, 2014 In: HERÊNCIO, 2017, p. 126)

\footnotetext{
${ }^{29}$ Famoso cabaré francês com orquestra itinerante.

30 Pianista, arranjador, compositor e regente. Estudou violino e harmonia em Paris tendo se formado no Conservatório Nacional na mesma classe de Jacques Thibaud.

31 Produtor e diretor de espetáculos musicais.
} 


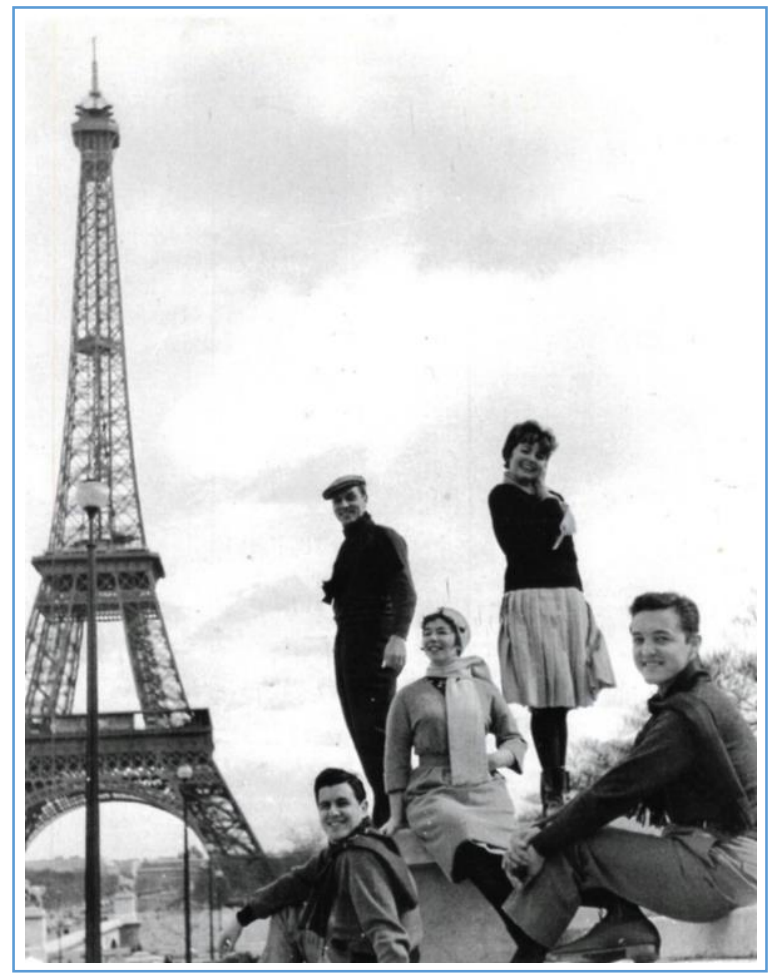

Imagem 1: Conjunto Farroupilha em Paris, 1958. Acervo pessoal Tasso Bangel ${ }^{32}$.

Na Varig, né? Então é isso, empresa internacional... E começamos então a fazer um repertório longo e grande de coisas estrangeiras que nós cantávamos e era muito interessante. Isso é uma outra parte do Farroupilha [...] que passou a ser nosso sucesso, talvez mais do que as [músicas] gaúchas, mesmo nós pilchados. (Tasso Bangel, comunicação pessoal em 10/04/2017)

\section{Nas asas da Panair: Rússia e China}

Chegamos à Suíça via Constellation, da Panair do Brasil. Nos hospedamos, ficamos um dia lá para no outro dia ir pra Rússia, Moscou.

[...] E também de Moscou para a China, para Pequim... Tivemos mais um mês e meio na China também. Xangai, Pequim, bah! Coisa linda! É, nós gostávamos de viajar! (Tasso Bangel, comunicação pessoal em 10/04/2017)

\footnotetext{
${ }^{32}$ Muitos documentos como fotografias, recortes de jornais, links de entrevistas e áudios da discografia do Conjunto Farroupilha estão disponíveis no site do Projeto de Pesquisa "Tasso Bangel e o eterno aprender": <https://www.ufrgs.br/tassobangel/>.
} 
Com a abertura ao repertório internacional, que passou a ser executado pelo Farroupilha com os mesmos primorosos arranjos vocais e interpretações do grupo, novos convites surgiram, dessa vez para chegar, literalmente, no outro lado do mundo.

[...] Até que [...] um homem, um comunista no Rio de Janeiro, que tinha ares de empresário também, conseguiu uma verba - até hoje não sei de onde, me consta que foi do Uruguai, não foi brasileira, porque nós não tínhamos relação com a Rússia naquele tempo - e [foi] fazer uma comissão cultural para a Rússia, para os países de lá. Então daí veio falar conosco por causa dessa experiência toda de música internacional que nós tínhamos, brasileira, gaúcha, e tudo o mais e tal, pra ir pra lá. E, lógico, nós sempre tivemos, de certa forma, um espírito aventureiro, gostávamos de viajar, até então não tínhamos filhos, nem eu, nem Danilo [...]. Nessa época a aventura nossa mais gostosa era viajar mesmo e... “Vamos pra Rússia?” “Vamos pra Rússia!” Então, lá fomos nós pra Rússia. (Tasso Bangel, comunicação pessoal em 10/04/2017)

Essa comissão cultural, segundo o Maestro Tasso, incluía também cantores do centro do país em franca ascensão no período, dentre eles, Dolores Duran, Jorge Goulart e Nora Ney, além do Conjunto Farroupilha. Para essa temporada em que compartilhavam os palcos, também estava previsto o acompanhamento de orquestra, tanto para o Conjunto como para os demais integrantes da trupe. Tudo indica que o gênero musical interpretado pelo coletivo brasileiro não era de conhecimento dos músicos de lá e a dificuldade de encontrar um regente que se sentisse à vontade para conduzir a orquestra interpretando música brasileira levou Tasso Bangel a assumir a batuta durante a temporada. Segundo o Maestro,

[...] e ainda sempre dentro daquela proposta, como nós liderávamos o grupo que tinha Dolores Duran, tinha Jorge Goulart, tinha Nora Ney, nesse grupo que foi pra Rússia, representando... promoção do Partido Comunista, feito pelo Partido Comunista. [...] Muito bem, então lá fomos nós pra Rússia. E também como sempre costuma acontecer, onde tava o Farroupilha tinha que ter orquestra. Sem orquestra nós não fazíamos, né? Então [era a] Orquestra da Rádio e Televisão de Moscou que nos acompanhava. Arranjos lindos que nós levamos, alguns do Lyrio Panicali, [do] Jorge Goulart, da turma da [Rádio] Nacional, arranjos do Radamés Gnattali, bah! Dolores Duran [cantarola trecho da melodia]. Isso era um sucesso da Dolores Duran! E... [cantarola outro trecho]. Então, lá fomos nós. Chegamos lá e "quem é que vai reger a orquestra?" Teve um regente que se apresentou lá e coisa mas daí - ele com as partituras todas 
- o primeiro ensaio “não, assim não vai dar, tá muito difícil...”. Então, "alguém...?" Então daí eu regi a orquestra da Rádio e Televisão de Moscou vestido de bombacha! [risos] Regi a temporada toda. Regi na Rússia e regi na China. [...] Nós tivemos um mês e meio viajando diversas cidades, Moscou, era Leningrado que hoje é São Petesburgo, bah.... Kiev [...]. Fizemos umas seis ou sete cidades da Rússia, diversos locais. Maravilha! (Tasso Bangel, comunicação pessoal em 10/04/2017)
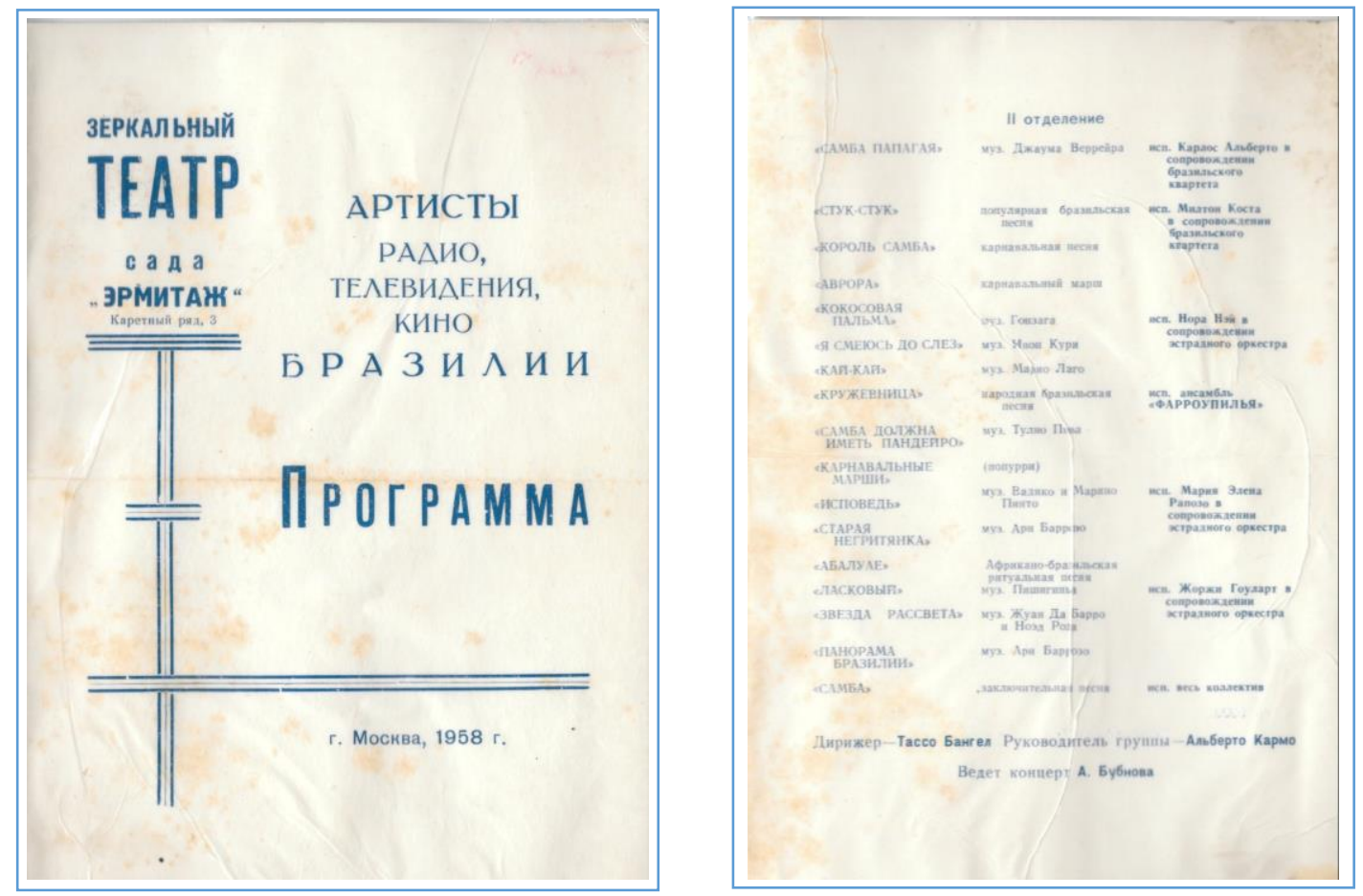

Imagem 2 e 3: Capa e excerto do interior do programa musical executado na Rússia em 1958. Acervo pessoal Tasso Bangel.

Dentre o repertório interpretado pela trupe, figurava o samba-canção "Por causa de você", composto em 1957, por Dolores Duran e Tom Jobim, que o Conjunto Farroupilha gravara nesse ano de 1958, esta que seria a segunda gravação da canção33 a que se seguiram outras dezenas nos anos seguintes.

E mais uma vez a temporada foi um grande sucesso a ponto de o grupo ser convidado para seguir viagem para a China34.

\footnotetext{
33 A primeira gravação de "Por causa de você" é de Sylvia Telles, no LP "Carícia", de 1957, com arranjos de Tom Jobim (JOBIM, 1996, p. 287).

34 Segundo o Dicionário Cravo Alvim, após a temporada na Rússia, Dolores Duran "decidiu abandonar o grupo e seguiu para Paris, onde ficou um mês se apresentando numa boate frequentada por brasileiros". Disponível em <http://dicionariompb.com.br/dolores-duran/dados-artisticos $>$. Acesso em 08/08/2017.
} 
Daí, logo que começamos em Moscou, que eles sentiram que o grupo todo tinha uma certa... uma expressão, era tanto o Jorge cantando - que era um grande cantor o Jorge Goulart -, voz grandona, né? A Nora Ney naquela personalidade dela. Então... "Vocês não querem ir pra China?" “Lógico que queremos!” Então, China! [...]

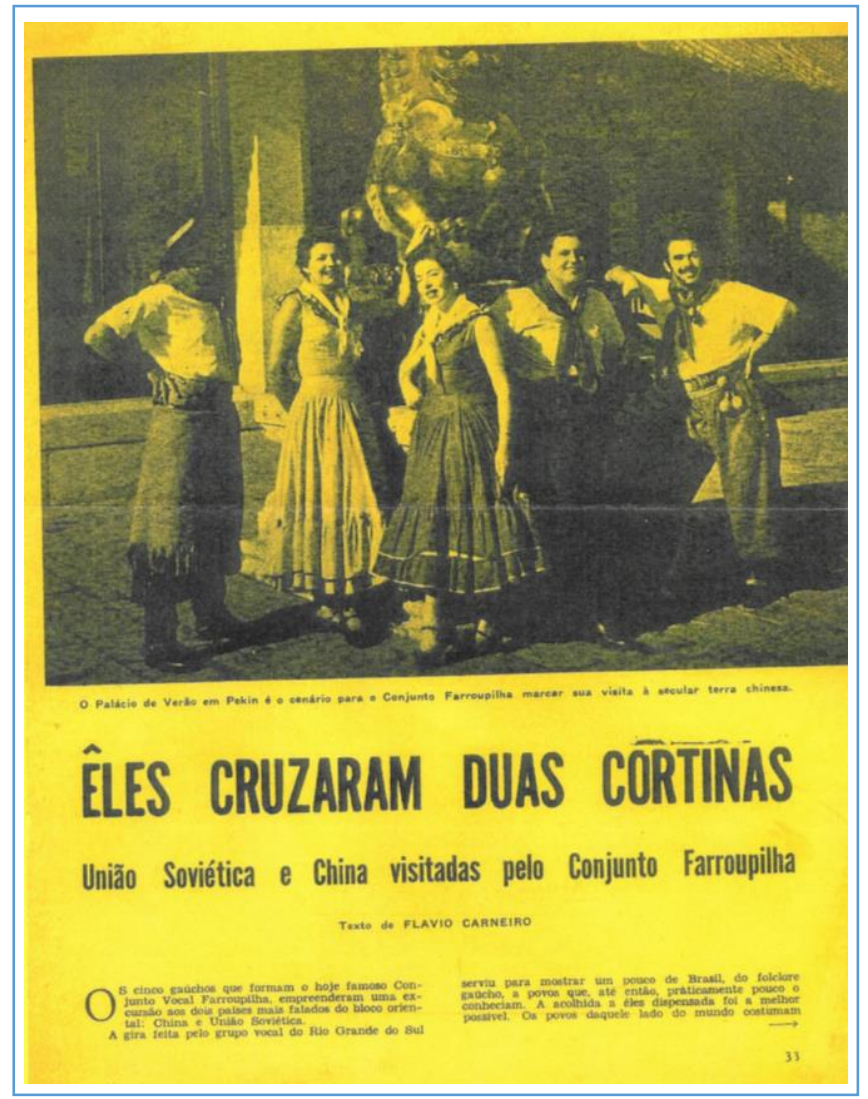

Imagem 4: Excerto de artigo de Flávio Carneiro, para a Revista do Globo, s/d. Acervo pessoal Tasso Bangel.

\section{Nota sobre a quase-temporada em Cuba}

O Conjunto Farroupilha quase não parou no Brasil em seu retorno. O produtivo ano de 1958 encerraria com uma temporada em Porto Rico e a promessa de seguirem para Cuba de onde pretendiam estabelecer-se em uma carreira internacional vindo, inclusive, a morar fora do Brasil por um tempo.

Nós saímos pra não voltar mais para o Brasil. 58 foi isso. Saímos de mala pronta. Estávamos trabalhando no Caribe Hilton, um hotel de Porto Rico, da cadeia Hilton, ficamos quinze dias trabalhando no Caribe Hilton, esperando que chegasse a hora da nossa temporada no Tropicana [Club] 
de Cuba. É. Por que o Tropicana? O Tropicana, como o maior cassino naquela época de Cuba, e onde que reunia o extrato do empresariado internacional. [...] Então lá, o empresário nosso disse "vocês vão estar lá no Tropicana e estando no Tropicana vocês vão ser ouvidos pela equipe que leva, que contrata para Europa, a equipe que contrata para a Ásia e a equipe dos Estados Unidos. Uma dessas equipes vai contratar vocês e vocês vão embora por muito tempo". Tanto que nós fomos para o Caribe Hilton já de malas prontas para não voltar mais no Brasil. (Tasso Bangel, comunicação pessoal em 10/04/2017)

Porém, às vésperas da ida do Conjunto Farroupilha para Cuba estourou a Revolução Cubana (01/01/1959) e todo o cenário se alterou, mudando os planos do grupo.

[...] Com tudo! Com partituras... e quando nos estávamos lá, em Porto Rico, o empresário chega chorando - praticamente - no hotel e... "uma desgraça, pô, como é que vai acontecer isso!". Pois muito bem, "não podemos mais ir pra lá". "Por quê?" "Porque a notícia é que um cara de lá chamado Fidel Castro entrou com as tropas em Cuba, tá uma guerra lá, não dá, fechou o Tropicana, não mais [...] Fechou o Tropicana, não vai dar mais pra... Não fomos mais para o Tropicana. E o que que vamos fazer? Aí ele disse: "Vou ver o que eu posso fazer". Daí o cara, sei lá, em algum lugar que ele tinha um escritório em Porto Rico, se articulou feito louco, telefonemas e coisa, bom, nós fomos pro México depois do México fomos pra Caracas, fizemos uma temporada grande em Caracas, uma temporada boa no México e voltamos pro Brasil. Não deu pra sair [risos]. Toda a roupa, repertório de orquestra, saímos, tínhamos certeza que não voltávamos tão cedo para o Brasil. Pretendíamos fazer do Farroupilha de nível internacional. Tudo isso por causa das músicas que nós cantávamos e tudo o mais. (Tasso Bangel, comunicação pessoal em 10/04/2017)

\section{Farroupilhas Bossa Nova}

Assim, de volta ao Brasil, no retorno de todas essas viagens à Europa, Rússia, China e América, gravaram o LP "Gaúchos na cidade”, com repertório que incluía sucessos das cidades visitadas no exterior, que acabaram por invadir o Brasil também, caso de “Liechtensteiner Polka (Kotscher / Lindt)" que se tornou um grande sucesso no país35.

\footnotetext{
35 O Maestro Tasso contou que essa música fez tanto sucesso no Rio Grande do Sul, que muitas pessoas pensaram tratar-se de uma música tradicional alemã trazida ao estado pelos imigrantes. Virou um hit nos kerbs e oktoberfests da região.
} 


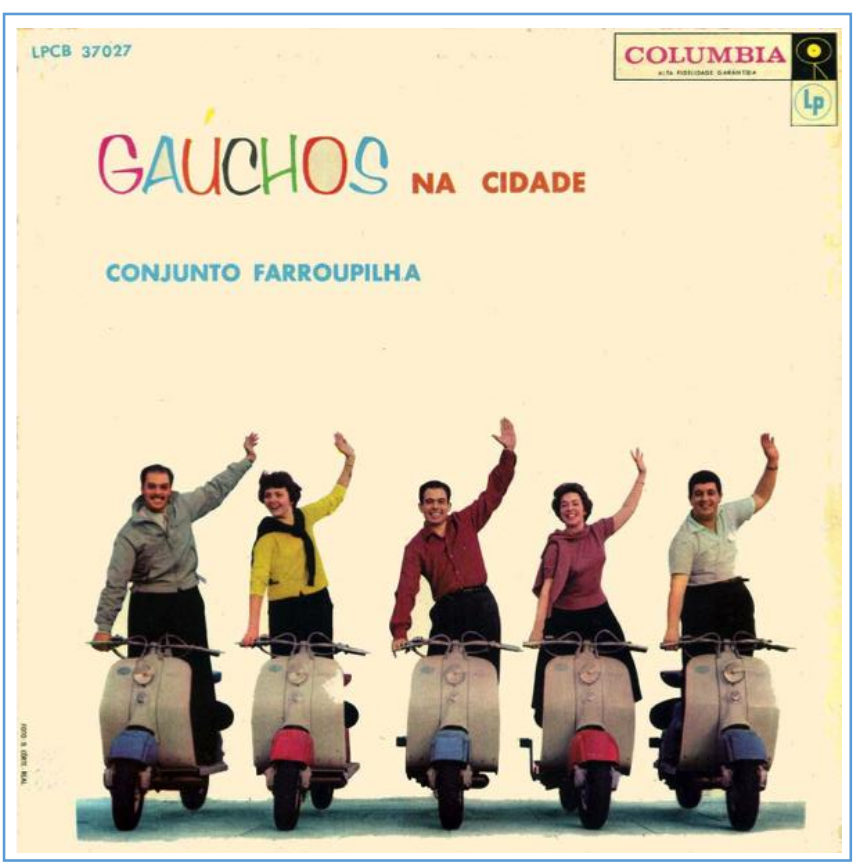

Imagem 5: Capa do LP Gaúchos na Cidade (1959).

Esse LP, além do repertório internacional que perfazia dez das doze faixas, abria com a bolero/bossa "Por causa de você", de Antônio Carlos Jobim e Dolores Duran (fruto da aproximação com a compositora durante a turnê pela Rússia e China) e com o samba do gaúcho Túlio Piva, "Tem que ter” (“O samba, pra ser samba brasileiro / tem que ter pandeiro/ tem que ter pandeiro/O samba, pra ser samba na batata/ tem que ter mulata / tem que ter mulata36"). Esse novo desenho de repertório e a capa do LP com o grupo sem as tradicionais pilchas, "gaúchos, não cavalgando seus 'pingos' mas esportivamente montados nas suas motonetas" (MACEDO, 1959), denotava a incorporação do Farroupilha como um produto de exportação, ligado a uma nascente indústria cultural transnacional, “moderna”, Bossa Nova. Na contracapa do disco, o jornalista Ricardo Macedo aponta para essa "virada" no perfil do grupo.

[...] Quando há alguns anos, travávamos os primeiros contatos com a arte deste notável Conjunto Farroupilha, através de um long-playing de músicas regionais do Sul, prevíamos uma carreira das mais brilhantes ao quinteto gaúcho. Mas, nem as mais otimistas previsões poderiam

\footnotetext{
${ }^{36}$ Vale assistir ao breve vídeo disponível na internet do músico russo Andrey Makarevich em que ele fala do impacto causado pelo Conjunto Farroupilha na Rússia, a ponto de terem gravado um EP por lá com vários sucessos. Mas é justamente a gravação deste samba, "Tem que ter", que marcou sobremaneira sua carreira. Disponível em: <https://www.youtube.com/watch?v=WQevOcNRBUY $>$. Acesso em 08/08/2017.
} 
antecipar o sucesso alcançado pelos Farroupilhas. Sua arte se expandiu de tal forma, que não mais poderia caber nos nossos oito milhões e tanto de quilômetros quadrados. Ultrapassou as fronteiras do Brasil, derramouse qual chuva benfazeja sobre os demais países da América, que a receberam com merecido entusiasmo. Aqueles cinco jovens, que haviam deixados seus "pagos" para tentar a sorte, trazendo apenas sua simpatia e o seu enorme talento, sentiram então regiamente recompensados seus esforços. Não apenas pelo sucesso financeiro do empreendimento, mas, acima de tudo, pela consagração do público, que é a maior paga do artista. No presente LP, ao contrário do que sucedeu com o primeiro prensado pela Columbia - Gaúchos em Hi-Fi - o Conjunto Farroupilha interpreta sucessos internacionais. Nele estão incluídos os êxitos mais recentes do quinteto - êxitos que figuraram com absoluto destaque em todas as "Paradas de sucessos" do Brasil: Mr. Lee, Clases de cha-cha-cha, Lieschtensteiner polka e outros. Revelam, sobretudo, a extraordinária versatilidade do Conjunto, que interpreta, com a mesma proficiência, músicas de procedência brasileira, alemã, americana, italiana, cubana, etc. (MACEDO, 1959)

É preciso mencionar que é nesse mesmo, 1959, que "Chega de saudade" recebe a versão no álbum homônimo de João Gilberto ("Chega de Saudade”, 1959), que seria posteriormente nomeada como aquela que "batizou" o novo gênero: o arranjo de orquestra cedendo à síntese proporcionada pelo violão (NAVES, 2004); a interpretação vocal coloquial de João Gilberto, sem vibratos e sem portamentos.

Nesse mesmo ano, o Conjunto Farroupilha grava três outras composições de Tom Jobim que serão lançadas em disco no ano seguinte: a segunda versão de "A felicidade"37, parceria com Vinícius de Moraes; e as primeiras versões de "Dindi”, parceria com Aloysio Oliveira e do "Samba de uma nota só", parceria com Newton Mendonça (JOBIM, 1996, p. 291 e 292).

Tasso Bangel reconstrói assim essa história de seu relacionamento com Tom Jobim:

[...] o que passou a ser nosso sucesso, talvez mais do que as [músicas] gaúchas, mesmo nós pilchados, a primeira gravação... no final de 58 pra 59, a primeira gravação do "Samba de Uma Nota Só" é nossa, é do Farroupilha. Depois o João Gilberto veio e foi pro mundo "eis aqui esse sambinha feito de uma nota só", né? Porque quando nós estávamos gravando o disco "Gaúchos em Hi-Fi" [...] - o "Gaúchos em Hi-Fi" é só

\footnotetext{
37 A primeira gravação da canção foi feito no mesmo ano de 1958 por Sylvio Mazzuca para a CBS (JOBIM, 1996, p. 291).
} 
gaúchas -, nós estávamos na Columbia gravando [...] e quem estava lá e nos ouviu foi Antônio Carlos Jobim. Ele tava gravando... tava lá porque ele tava gravando a Maysa, [ela] tava cantando coisas dele. Ele tava lá, vendo, esperando hora pra entrar pra gravar e fazer... editar as coisas lá. Ele nos ouviu. Acho que pela primeira vez Antônio Carlos Jobim nos ouviu cantando essas coisas gaúchas. E o Jobim, ele é filho... tem ascendência gaúcha. O pai dele era gaúcho... Ele pegou... falou: "Quem é o arranjador?" "Sou eu". "Então muito bem". Tirou um papelzinho, desenrolou: "Samba de uma nota só". E ele: "Esse é um samba que eu fiz. Se vocês se interessarem". [Eu] Disse: “Deixa comigo!” Eu não sabia quem era ele. Se ele era bom, se ele não era, que era. Então, Tom Jobim não era ninguém a essa altura [risos]. Porque ainda a Bossa Nova não tinha deslanchado. Comecinho de tudo, 1958, né? Comecinho. Então, lógico [o Maestro começa a tocar o "Samba de uma nota só" ao piano, enquanto continua a entrevista], veneno puro, né? [referindo-se aos acordes expandidos]. Me encantei com a coisa. Lindo! Bah! E gravamos com essa harmonia toda. Linda a música. [...] Um arranjo lindo do Lyrio Panicali. Mas que lindo o arranjo! E nós gravamos isso. Acho que foi espetacular. Nem foi sucesso porque ainda a Bossa Nova não era, né? Nós ainda vendíamos muito mais gaúcho do que outra coisa qualquer. Mas estávamos metidos [com a Bossa Nova] assim como também [cantando] "o pato / vinha cantando alegremente..." foi uma gravação nossa, porque nós éramos um conjunto do tal de "O Pato", apesar de ser sucesso do João Gilberto. Mas daí [...] o repertório todo de Bossa Nova [passou a ser interpretado] junto com o repertório que já existia do Farroupilha. (Tasso Bangel, comunicação pessoal em 10/04/2017)

\section{México, Las Vegas e Nova York}

No ano seguinte, 1960, a produtividade do Conjunto Farroupilha só aumentou. Neste ano, lançaram dois LPs pela Columbia.

"Os Farroupilhas na TV”, mais um marco na carreira do grupo, contou com os arranjos de Lyrio Panicali para, como vimos, os primeiros registros de "Dindi" e de "Samba de uma nota só38", música que se tornou um símbolo da Bossa Nova (HOMEM; OLIVEIRA, 2012, p. 103). Além dessas canções, como mencionado pelo Maestro Tasso, realizaram também uma das primeiras gravações de "O Pato", de Jaime Silva e Neusa Teixeira.

\footnotetext{
${ }^{38}$ Com o auxílio do jornalista Zeca Azevedo, a quem agradeço, compartilho o link com o áudio dessa gravação rara: <https://www.youtube.com/watch?v=pBVGdmfOUmA\&feature=youtu.be\&t=577 2 .
} 
Com esse LP, já com o padrão rítmico da Bossa Nova totalmente incorporado à orquestra na forma de ataques homorrítmicos dos diversos instrumentos nos arranjos, os Farroupilhas se lançam mais do que nunca na estética bossa-novística.

É preciso chamar a atenção que neste mesmo ano, João Gilberto lança o LP "O amor, o sorriso e a flor", pela Odeon, onde também constavam "O Pato" e "Samba de uma nota só", entre outras composições que posteriormente se tornariam ícones da Bossa Nova.

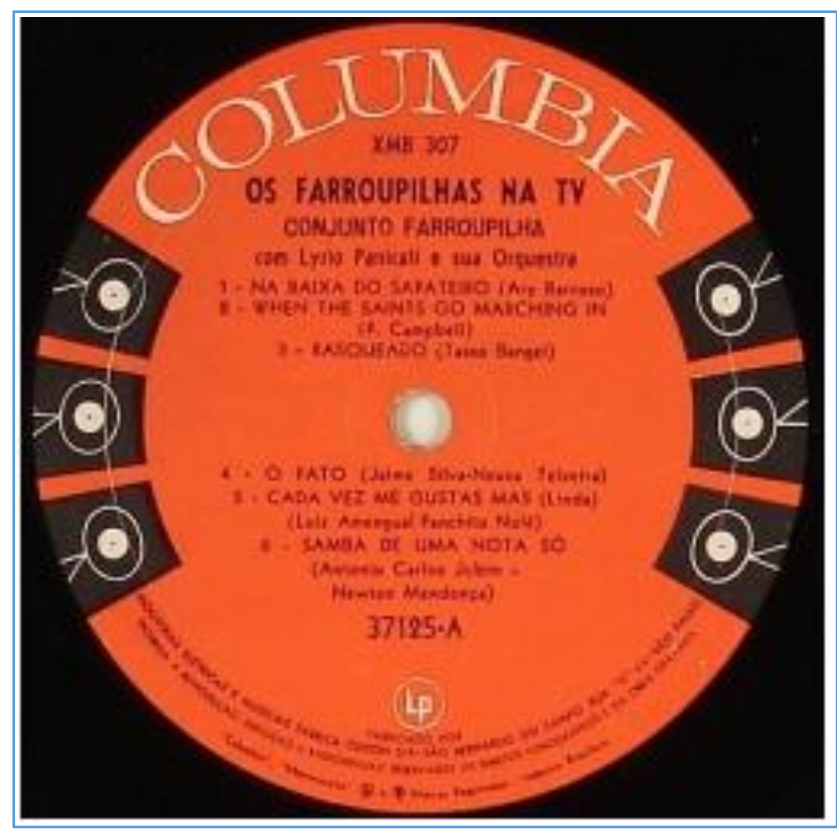

Imagem 6: Rótulo do LP Os Farroupilhas na TV - 1960.

O segundo LP lançado nesse mesmo ano de 1960 foi "Farroupilhas em Hi-Fi", no qual retomam a gravação de repertório "regional”, trazendo, no Lado A, novas composições dos gaúchos Barbosa Lessa e Paixão Cortes como "Balaio", além de uma composição de Luis Cosme ("Gauchinha") e uma de Altivo Penteado, o "Garoto" ("Meu Rio Grande"); e no Lado B, o repertório de samba e Bossa Nova que incluía "Nunca”, de Lupicínio Rodrigues e "A felicidade”, de Tom Jobim e Vinícius de Moraes (gravada em 1959). Novamente o que amalgamava esse repertório tão distinto entre si eram os arranjos vocais característicos do grupo. 
O sucesso dos discos mais uma vez colocou o grupo para voar. Agora literais portavozes da Bossa Nova são convidados para excursionar nos Estados Unidos e no México. Capa da revista Radiolândia de dezembro de 1960, os jornalistas do veículo comentaram assim a turnê do grupo:

A capa desta Radiolândia é um justo preito a este homogêneo grupo de artistas brasileiros que se chama Conjunto Farroupilha. Gaúchos, amando profundamente as tradições e as raízes da música do seu rincão, eles no entanto transformam-se em intérpretes internacionais quando necessário. Suas gravações expressam a variedade de ritmos e idiomas que são capazes de interpretar, desde a polca alemã até às canções francesas, sem contar com as músicas populares e folclóricas do Brasil. Nesta homenagem [...] relembramos algumas das suas apresentações vitoriosas em nossa terra, agora que eles brilham no palco do Radio City de Nova York. O Conjunto Farroupilha, além de ter-se apresentado em todo o nosso território, já viajou pela Europa e Ásia, e, ao que tudo indica, deverá permanecer muito tempo nos Estados Unidos. (Revista Radiolândia, 1960, S/A, s/p)

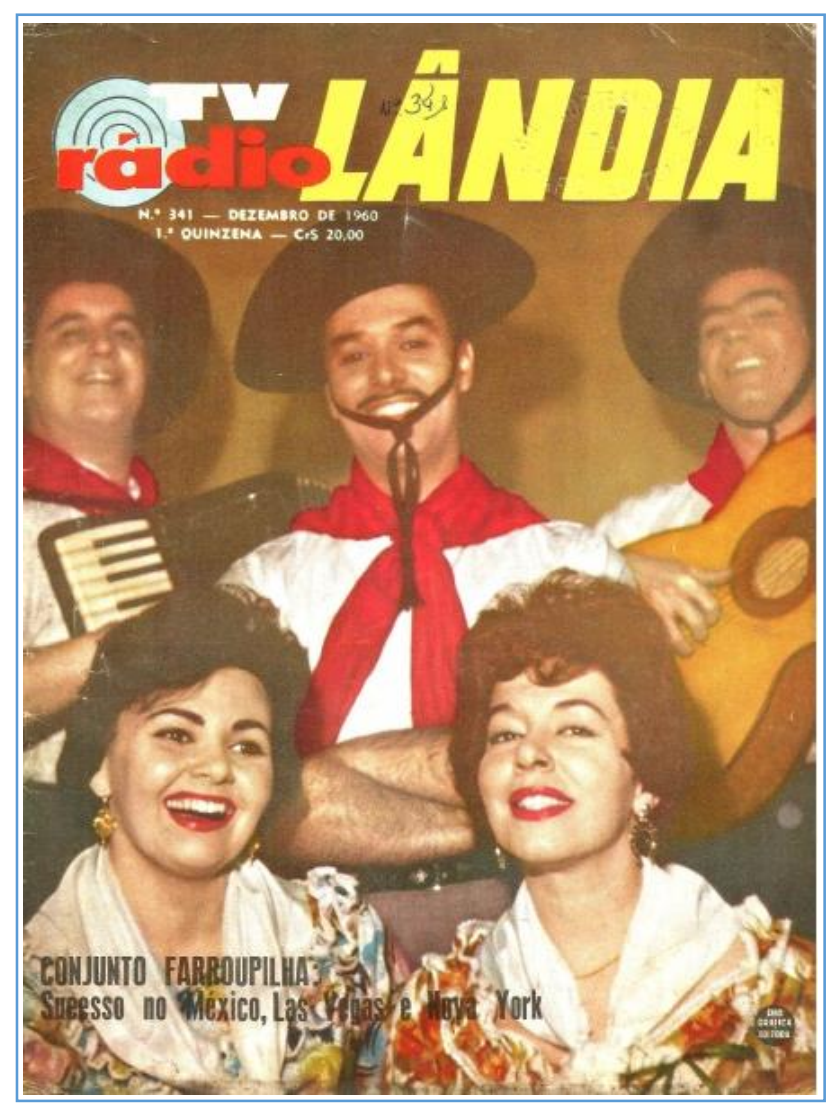

Imagem 7: Capa da Revista Radiolândia de dezembro de 1960. 

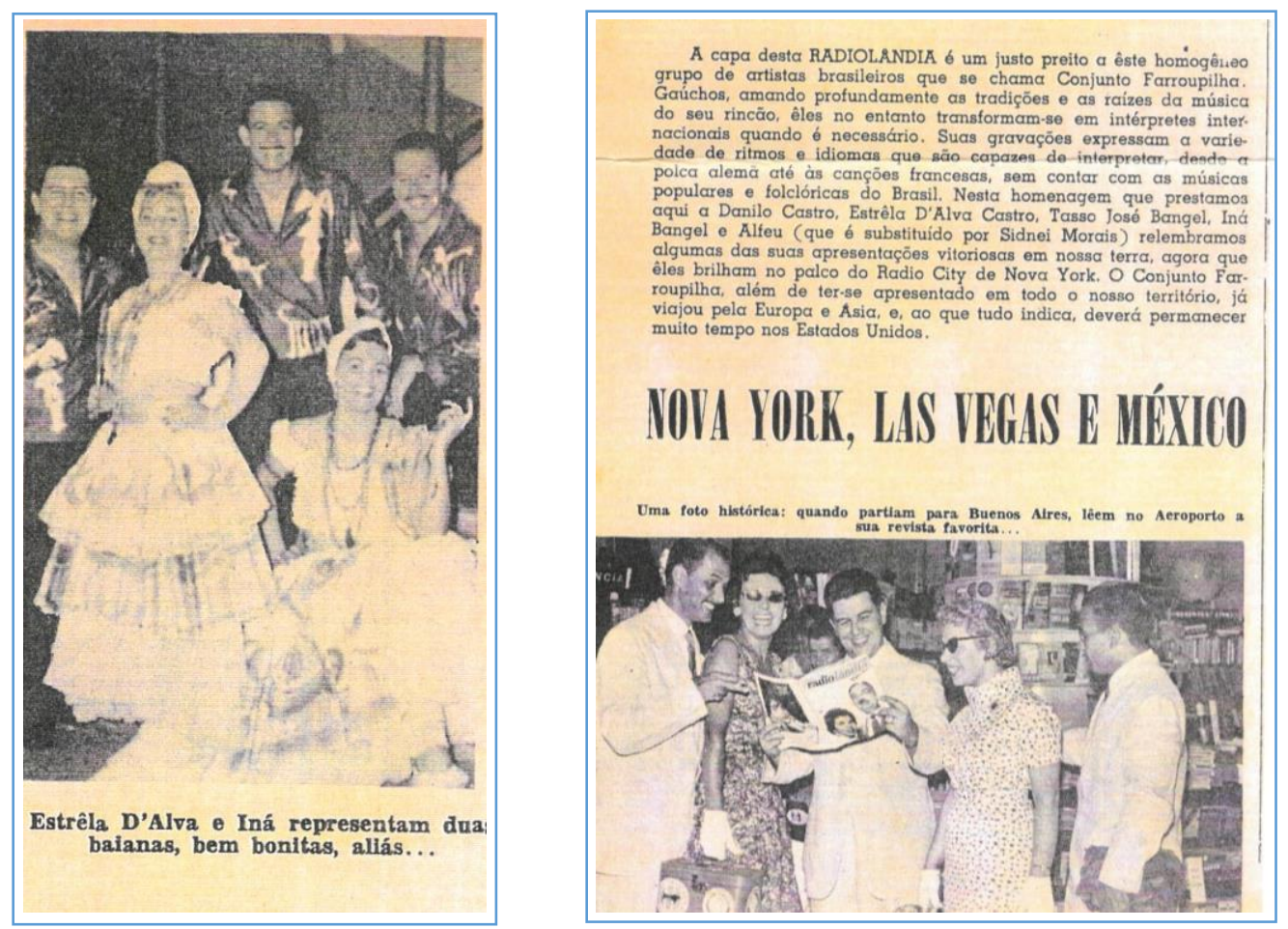

Imagens 8 e 9: Páginas internas da Revista Radiolândia de dezembro de 1960. Acervo pessoal Tasso Bangel.

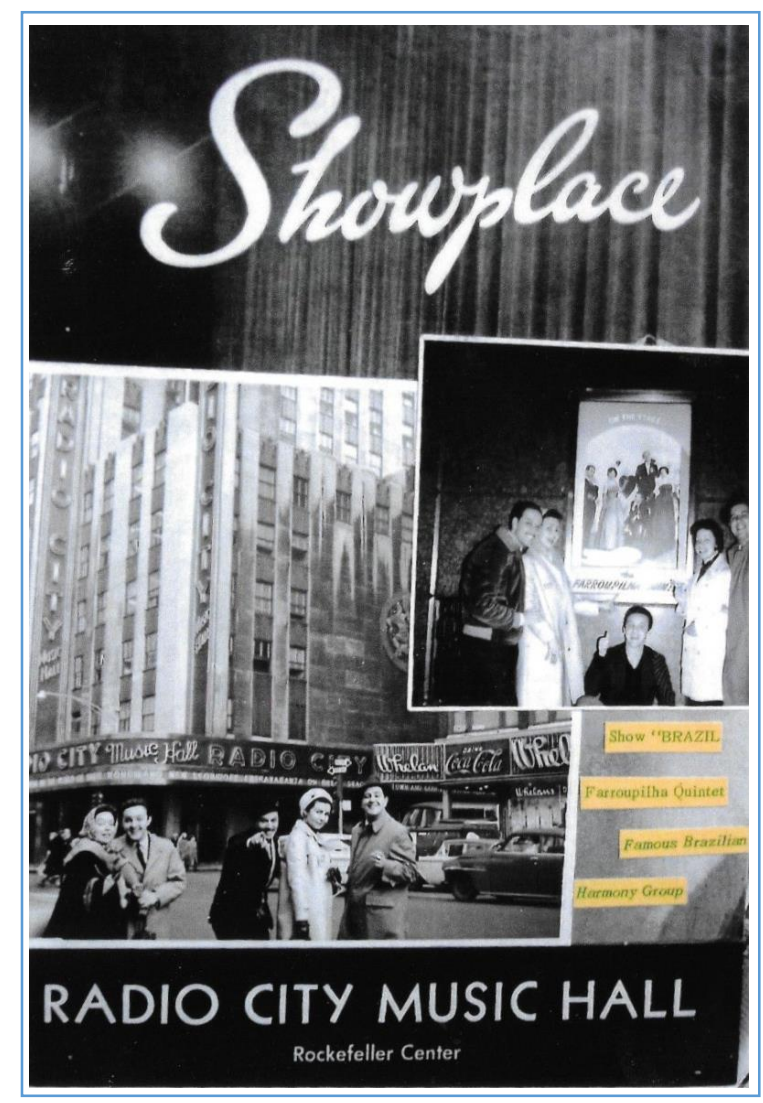

Imagem 10: Cartaz do show em Nova York:

"Show Brazil, Farroupilha Quintet, Famous Brazilian Harmony Group". Acervo pessoal Tasso Bangel. 


\section{Coda}

O Conjunto Farroupilha, portanto, chegou à Nova York trazendo na bagagem, entre tantas canções gaúchas, brasileiras e internacionais, "Samba de uma nota só", "O pato" e "A felicidade", dois anos antes de ocorrer o histórico concerto Bossa Nova no Carnegie Hall que levou Tom Jobim, João Gilberto e outros vinte artistas brasileiros pela primeira vez aos palcos americanos, graças ao auxílio do Ministério das Relações Exteriores do Brasil (JOBIM, 1996, p. 111).

Nos anos seguintes, o Conjunto Farroupilha seguiu em sua carreira no Brasil e no exterior, inclusive gravando para a BBC de Londres sob os olhares curiosos dos nascentes “Beatles39". Gravaram outros LPs, criaram um selo fonográfico (AZEVEDO, 2017) e seguiram unidos até uma primeira parada do grupo em 1971 quando a onda do lê-iê-iê já dominava as paradas de sucesso no país. Retomaram as atividades anos depois em 1983 e seguiram realizando apresentações até 1990, ano do falecimento de Inah Bangel.

Do período aqui descrito, muitas coisas saltam aos ouvidos. Ao mesmo tempo em que o Conjunto Farroupilha começa suas atividades em Porto Alegre a partir de uma cultura musical muito ampla, incluindo especialmente as influências do jazz das grandes orquestras americanas e do tango dos países do Prata, assumem a bandeira de divulgar o “estilo gaúcho” na música (BANGEL, 1984), proposta pelos folcloristas Barbosa Lessa e Paixão Cortes. Esse repertório de “música gaúcha”, portanto, passou a ser o carro-chefe dos primeiros anos do grupo e o que o lançou nas emergentes experiências de grande sucesso de público e crítica. Tasso Bangel devota aos dois amigos, Lessa e Cortes, um enorme reconhecimento pelo caminho trilhado pelo Conjunto Farroupilha, mas acrescenta que a interpretação que o grupo imprimiu ao seu repertório através dos arranjos vocais e orquestrais, com grande apuro harmônico, tenha sido o principal motivo para a música do Rio Grande do Sul ter alcançado o mercado fonográfico e aberto caminhos para músicos e compositores que os seguiram.

\footnotetext{
39 Essa história, do encontro com os Beatles, foi contada pelo Maestro Tasso Bangel no programa Teledomingo da RBS TV, afiliada da Rede Globo. Disponível em <http://g1.globo.com/rs/rio-grande-dosul/noticia/2014/06/beatles-pararam-para-ver-grupo-do-rs-em-londres-nos-anos-60-diz-musico.html. Acesso em 05/08/2017.
} 
Tanto que eu acho que as coisas que aconteceram com o Farroupilha justamente porque nós viemos com essa força, com orquestra, com harmonização, conjunto, quer dizer, sabe? Nós preenchemos uma lacuna que não era nada calculado nosso mas casualmente aconteceu aquilo para o Rio Grande da forma que nós fizemos. E surgiu o Barbosa Lessa que era um baita cara, lindo! O Barbosa era a "cabeça" do Rio Grande e o Paixão as "pernas", porque das danças tudo era o Paixão. "Chirimindé", "Ratoeira", aquelas droguinhas todas do folclore mesmo, recolhido por eles, como um valor imenso. Mas a cabeça sempre foi o Barbosa Lessa. (Maestro Tasso Bangel, comunicação pessoal em 10/04/2017)

Entendida como um processo comunicacional que extrapola o código musical per se, Lucas (2004, s/p) nos permite compreender "as complexidades envolvidas no processo de significação musical”. Alinhada a Feld (1984), a autora alerta que

O processo de significado musical depende da interação dialética entre o "produtor de código" e o "consumidor de mensagens". As análises que não levam em conta este fato podem oferecer apenas uma visão parcial do processo de comunicação. No caso de músicas, essa interação dialética está ligada ao contexto em que a cadeia produtor-códigoreceptor se intercepta. Conseqüentemente, a performance real e os aspectos musicais embutidos nessas músicas devem ser integrados na análise, pois formam a situação contextual imediata em que o significado da música é interpretado. Para resumir meu argumento, as músicas são aqui concebidas como um sistema semiótico socialmente construído. Portanto, a análise de signos em músicas leva em consideração a relação entre dispositivos sonoros / textuais / performativos e o contexto específico em que as músicas se tornam significativas para os ouvintes que são membros de um grupo sociocultural, um argumento que levanta a questão da performance ao vivo. (LUCAS, 2004, s/p) ${ }^{40}$

A performance do Farroupilha, nesse viés é, portanto, compreendida como o grande vetor do desenvolvimento do grupo. Somado ao repertório gaúcho, a bagagem de música internacional já acumulada nos anos da Rádio Farroupilha permitiu que o

\footnotetext{
${ }^{40}$ No original: "[...] the process of musical meaning depends on the dialectical interaction between 'codeproducer' and 'message-consumer'. Analyses that do not take this fact into account can offer only a partial view of the communication process. In the case of songs, this dialectical interaction is tied up to the context in which the chain producer-code-receptor intersects. Consequently the actual performance and the musical settings in which these songs are embedded should be integrated in the analysis for they form the immediate contextual situation in which song meaning is interpreted. To sum up my argument, songs are here conceived as a semiotic system that is socially constructed. Therefore, the analysis of sign vehicles in songs takes into account the relationship between sound/textual/performative devices and the specific context in which songs become meaningful to listeners qua members of a sociocultural group, an argument that brings out the question of live performance" (LUCAS, 2004, s/p).
} 
Conjunto Farroupilha estivesse sempre aberto aos desafios que sua internacionalização, concretamente, passou a lhes exigir a partir de seus deslocamentos por inúmeros países.

Como explica Faria ainda sobre as experiências sonoras proporcionadas pela Rádio Farroupilha, em sua fase áurea, nos 50 e 60,

[...] o repertório era vastíssimo. Tinha de tudo, em grandes quantidades: muita música centro-americana (do Caribe ao México, com uma bela parada em Cuba e toda sua variedade de ritmos agrupada sob o rótulo de salsa, rumba ou mambo - além de uma avassaladora quantidade de boleros, uma onda forte de guarânias paraguaias, muitíssima música pop norte-americana de então (swing, fox, temas de filmes, standards variados), tangos dos anos 30 e 40 e todos os sucessos de música 'brasileira' de todas as épocas". (FARIA, 2001, p. 102 e 103)

O Conjunto Farroupilha aproveitou de toda essa riqueza musical de seu ambiente originário, bem como, das musicalidades compartilhadas em suas vivências futuras, sempre mantendo as características performativas - os arranjos, o profissionalismo, o rigor interpretativo -, o "feitio" que marcou toda sua carreira e que ainda segue vivo na atuação contemporânea do Maestro Tasso Bangel, hoje à frente da Camerata Pampeana, grupo predominantemente instrumental formado por dois violinos, viola, cello, violão, contrabaixo e acordeom, este último interpretado pelo próprio Maestro.

O Farroupilha passou a ter um repertório de música internacional, de música nacional, esse tipo de coisas assim, né? Praticamos todos os estilos praticamente, mas dentro daquele feitio do conjunto. (Tasso Bangel, comunicação pessoal em 10/04/2017)

Por fim, do ponto de vista do que o Conjunto Farroupilha contribuiu para a difusão da Bossa Nova mundo afora, muito ainda precisa ser pesquisado e divulgado. Mas o fato de terem realizado algumas das primeiras gravações de canções emblemáticas do gênero e tê-las divulgado em várias cidades do mundo como Moscou e Nova York, por exemplo, antes ainda dos próprios Tom Jobim e João Gilberto, já nos garante a possibilidade de afirmar que muito da história da música popular do país precisa ser escrita a partir de outros lugares - geográficos e epistemológicos -, fora do eixo Rio-São Paulo, do norte, 
do sul, com vistas a quem sabe, "sulear" nossa compreensão de mundo, como propôs Freire (1991).

O Conjunto Farroupilha esteve em cartaz por várias semanas no Music City Hall em Nova York, em 1960. No ano seguinte, começam a aparecer as primeiras gravações de Bossa Nova no exterior: o acordeonista francês Jo Basile grava "A felicidade"; o violonista brasileiro Laurindo Almeida radicado nos EUA grava "Samba de uma nota só" assim como o trombonista Curtis Fuller e Shorty Rogers \& His Giants, que também interpreta "Chega de saudade" em um disco totalmente dedicado à Bossa Nova; Sylvia Telles grava nos EUA "Estrada do sol" e "Amor sem Adeus" (Jobim, 1996, p. 309 e 310). Em 1962, Stan Getz e Charlie Bird lançam o LP Jazz Samba que incluía a gravação de "Samba de uma nota só" e de "Desafinado" "que permaneceu setenta semanas nas paradas da Billboard" (SCARABELOT, 2004, p. 3) quando somente em dezembro desse ano iria acontecer o concerto Bossa Nova no Carnegie Hall.

Qual a exata contribuição do Conjunto Farroupilha nesse processo de difusão da música brasileira como um todo, e da Bossa Nova, em especial, ainda está por vir à tona, mesmo que para o Maestro Tasso Bangel, tudo tenha acontecido simplesmente porque tinha que acontecer.

Então é isso: as coisas aconteceram não programadas. Foram acontecendo porque nós trazíamos algumas novidades. Não calculada. Quando calculamos alguma coisa, não deu! [risos]. Nós queríamos o mercado internacional. É isso aí! (Tasso Bangel, comunicação pessoal em 10/04/2017).

\section{Referências}

ÁVILA, Fernando Henrique Machado. Os Irmãos Bertussi e a música regional de baile no Rio Grande do Sul. Porto Alegre: DEMUS/ UFRGS, 2015. Projeto de Graduação em Música Popular. Disponível em: <http://www.lume.ufrgs.br/handle/10183/131810 $\geq$. Acesso em 02/07/2017. 
ALBERNAZ, Pablo de Castro. A música e o lembrar: memórias dos músicos da centenária Banda Rossini. In: LUCAS, Maria Elizabeth (Org.). Mixagens em campo: etnomusicologia, performance e diversidade musical. Porto Alegre: MarcaVisual, 2013, p. 235-252.

AZEVEDO, Zeca. Precisamos resgatar a história e a discografia do Conjunto Farroupilha. Sul21, 01/04/2017. Disponível em https://www.sul21.com.br/jornal/precisamos-resgatar-ahistoria-e-a-discografia-do-conjunto-farroupilha/. Acesso em 20/08/2017.

BANGEL, Tasso. 0 estilo gaúcho na música brasileira. Porto Alegre: Editora Movimento, 1987.

BANGEL, Tasso. Tasso Bangel: entrevista. Entrevistadora: Luciana Prass. Porto Alegre: 16 de março de 2011. Digi.

BANGEL, Tasso. Tasso Bangel: entrevista. Entrevistadora Luciana Prass e Gabriela Lery Borges. Porto Alegre: 24 de setembro de 2013. Digi.

BANGEL, Tasso. Tasso Bangel: depoimento. Depoimento em aula da disciplina de música popular do Brasil II da UFRGS. Porto Alegre: 20 de outubro de 2013. Digi.

BANGEL, Tasso. Tasso Bangel: entrevista. Entrevistadora: Carla Fachim. Programa "Teledomingo", da RBS TV, emissora afiliada da Rede Globo de Televisão. Disponível em http://g1.globo.com/rs/rio-grande-do-sul/noticia/2014/06/beatles-pararam-para-ver-grupodo-rs-em-londres-nos-anos-60-diz-musico.html. Acesso em 05/08/2017. Porto Alegre: $1^{\circ}$ de junho de 2014.

BANGEL, Tasso. Tasso Bangel: entrevista. Entrevistadora: Luciana Prass, Bruno Muck, Felipe Barreto e Aretha Lima. Porto Alegre: 10 de abril de 2017. Digi.

BARBOSA, Valdinha; DEVOS, Anne Marie. Radamés Gnattali, o eterno experimentador. Rio de Janeiro: FUNARTE, 1985.

BASTOS, Rafael José de Menezes. Prefácio. In: COELHO, Luís Fernando Hering. Os músicos transeuntes: de palavras e coisas em torno de uns Batutas. Itajaí: Casa Aberta Editora, 2013, p. 9-13.

BORGES, Gabriela Lery. Maestro Tasso Bangel: sua trajetória do Conjunto Farroupilha (1948 - 1990) à Camerata Pampeana (2010 -). In: STEIN, Marília; RAJOBAC, Raimundo; PRASS, Luciana (Orgs.). In: MUSPOPUNI, I, Porto Alegre, 2015. Anais... Porto Alegre: Marcavisual, 2015. p. 553. Disponível em:

http://www.ufrgs.br/musicapopularnauniversidade. Acesso em 29 de junho de 2017.

CASTRO, Ruy. Carmen. São Paulo: Companhia das Letras, 2005. 
COELHO, Luís Fernando Hering. Os músicos transeuntes: de palavras e coisas em torno de uns Batutas. Itajaí: Casa Aberta, 2013.

CONJUNTO FARROUPILHA. Gaúcho. São Paulo: Long Play Radio, 1953. LP.

CONJUNTO FARROUPILHA. De norte a sul. São Paulo: Odeon, 1956. LP.

CONJUNTO FARROUPILHA. Gaúchos em Hi-Fi. Rio de Janeiro: Columbia, 1957. LP.

CONJUNTO FARROUPILHA. Gaúchos na cidade. Rio de Janeiro: Columbia, 1959. LP.

CONJUNTO FARROUPILHA. Os Farroupilhas em Hi-Fi. Rio de Janeiro: Columbia, 1960. LP.

CONJUNTO FARROUPILHA. Os Farroupilhas na TV. Rio de Janeiro: Columbia, 1960. LP.

CÔRTES, João Carlos Paixão; LESSA, Luis Carlos. Manual de danças gaúchas. São Paulo: Irmãos Vittale, 1987 [1955].

FARIA, Arthur de. Um século de música no RS. Porto Alegre: CEEE, 2001.

FELD, Steven. The Practice of Everyday Life. Berkeley: University of Califórnia Press, 1984.

FERREIRA, Clarissa. Campeirismo musical e os festivais de música nativista do sul do Brasil: a (pós) modernidade (re) construindo o "gaúcho de verdade". Dissertação de mestrado, Musicologia/ Etnomusicologia, Universidade Federal do Rio Grande do Sul, 2014(a).

FERREIRA, Clarissa. Nem chinoca, nem flor, nem morocha! Sobre o machismo e a música gauchesca (Parte I). Gauchismo líquido, 21 de novembro de 2014(b). Disponível em http://gauchismoliquido.blogspot.com.br/2014/11/nem-chinoca-nem-flor-nem-morochasobre.html. Acesso em 14 de dezembro de 2017.

FREIRE, Paulo. Pedagogia da esperança: um reencontro com a pedagogia do oprimido. São Paulo: Paz e Terra, 1991.

HERÊNCIO, Diego. Conjunto Farroupilha: análise histórica e investigação de suas influências para a música do Rio Grande do Sul. Revista da Fundarte, ano 17, n. 33, jan. a jul, 2017. p. 114-136. Disponível em:

http://seer.fundarte.rs.gov.br/index.php/RevistadaFundarte/article/view/439/550. Acesso em 07 de agosto de 2017. 
HOMEM, Wagner; OLIVEIRA, Roberto. Histórias de canções: Tom Jobim. São Paulo: Lya, 2012.

JOBIM, Helena. Antônio Carlos Jobim: um homem iluminado. Rio de Janeiro: Nova Fronteira, 1996.

LESSA, Barbosa. Nativismo: um fenômeno social gaúcho. Porto Alegre: L\&PM, 1985.

LUCAS, Maria Elizabeth. Brasilhana: the making of a transcultural musical sign. España:

Trans - Revista Transcultural de Música, núm. 8, 2004.

LUCAS, Maria Elizabeth. Identidade Sonora. In: Gonzaga, Sergius et allii. (Org.). Nós, os Gaúchos. 1a ed. Porto Alegre: Editora da Universidade, 1994, v. 2, p. 139-143.

LUCAS, Maria Elizabeth. Gauchos on Stage: Regionalism, Social Imagination and Tradition in the Festivals of Música Nativa, Rio Grande do Sul, Brazil. 1900. Tese (doutorado) University of Texas System, Estados Unidos, 1990.

MACEDO, Ricardo. Gaúchos na cidade: Conjunto Farroupilha. Contracapa do LP. Rio de Janeiro: Copacabana, 1959.

MUSTAFÁ, Izani. O uso político do rádio pelos ditadores Getúlio Vargas (Brasil) e António de Oliveira Salazar (Portugal) no período de 1930 - 1945. Porto Alegre: PPGCOM/PUCRS, 2014. Tese de Doutorado.

NAVES, Santuza Cambraia. Da bossa nova à tropicália. Rio de Janeiro: Zahar, 2004.

PRASS, Luciana. Maçambiques, quicumbis e ensaios de promessa: musicalidades quilombolas do sul do Brasil. Porto Alegre: Editora Sulina, 2013.

S/A. O melhor conjunto vocal do ano. A Noite. Rio de Janeiro, 1957.

S/A. Contracapa do LP. Conjunto Farroupilha - de norte a sul. Rio de Janeiro: Odeon, 1956.

SCARABELOT, André. Música brasileira e jazz - o outro lado da história: Entrevistas com músicos jazzistas. Revista Digital Art\&. Ano II, n. 2, p. 1-6, out 2004. Disponível em http://www.revista.art.br/site-numero-03/trabalhos/07.htm. Acesso em 04/07/2017.

SCHMITT, Marta. Clube do Guri: a história de um dos maiores sucessos do rádio gaúcho das décadas de 50 e 60. Porto Alegre: [s. ed.], 2008. 
SOUZA, Marcio de. Espia só... a trajetória musical de Octávio Dutra. Porto Alegre, Laser Press, 2016.

TITON, Jeff Todd. Knowing Fieldwork. In: Barz, Gregory; Cooley, Timothy. (eds.). Shadows in the field: new perspectives for fieldwork in ethnomusicology. New York: Oxford University Press, 1997.

VIANNA, Hermano. O mistério do samba. Rio de Janeiro: Zahar, 1995.

VILHENA, Luís Rodolfo. Projeto e missão: o movimento folclórico brasileiro 1947-1964. Rio de Janeiro: Funarte: Fundação Getúlio Vargas, 1997.

WERNER, Kenia. Entre cabarés, noites líricas e rádios porto-alegrenses: a trajetória do músico Roberto Eggers (1889-1984). Dissertação de mestrado, Música, Universidade Federal de Minas Gerais, 2012. 